8-1994

\title{
Cultural Resources Survey and Monitoring of Joint Task Force Six (JTF-6) Actions in Webb, Zapata, Dimmit, La Salle, Duvall, and Jim Hogg Counties, Texas
}

Stephen P. Austin

Geo-Marine, Inc.

Scott Ferguson

Geo-Marine, Inc.

Steven M. Hunt

Geo-Marine, Inc.

Floyd B. Largent Jr.

Geo-Marine, Inc.

Mark A. Sale

Geo-Marine, Inc.

Follow this and additional works at: https://scholarworks.sfasu.edu/ita

Part of the American Material Culture Commons, Archaeological Anthropology Commons, Environmental Studies Commons, Other American Studies Commons, Other Arts and Humanities Commons, Other History of Art, Architecture, and Archaeology Commons, and the United States History Commons

Tell us how this article helped you.

This Article is brought to you for free and open access by the Center for Regional Heritage Research at SFA ScholarWorks. It has been accepted for inclusion in Index of Texas Archaeology: Open Access Gray Literature from the Lone Star State by an authorized editor of SFA ScholarWorks. For more information, please contact cdsscholarworks@sfasu.edu. 
Cultural Resources Survey and Monitoring of Joint Task Force Six (JTF-6) Actions in Webb, Zapata, Dimmit, La Salle, Duvall, and Jim Hogg Counties, Texas

\section{Creative Commons License}

\section{(c) (i) $\Theta($}

This work is licensed under a Creative Commons Attribution-NonCommercial-No Derivative Works 4.0 International License. 


\begin{tabular}{|c|c|c|c|c|c|c|c|}
\hline \multicolumn{7}{|c|}{ REPORT DOCUMENTATION PAGE } & \multirow[t]{2}{*}{$\begin{array}{l}\text { Form Approved } \\
\text { OMB No. } 0704-0188\end{array}$} \\
\hline \multicolumn{4}{|c|}{$\begin{array}{l}\text { 1a. REPORT SECURITY CLASSIFICATION } \\
\text { Unclassified }\end{array}$} & \multicolumn{3}{|c|}{ 1b. RESTRICTIVE MARKINGS } & \\
\hline \multicolumn{4}{|c|}{ 2a. SECURITY CLASSIFICATION AUTHORITY } & \multicolumn{4}{|c|}{$\begin{array}{l}\text { 3. DISTRIBUTIONAVAILABILITY OF REPORT } \\
\text { Approved for public release }\end{array}$} \\
\hline \multicolumn{4}{|c|}{$\begin{array}{l}\text { 4. PERFORMING ORGANIZATION REPORT NUMBERS } \\
\text { Miscellaneous Report of Investigations No. } 63\end{array}$} & \multicolumn{4}{|c|}{ 5. MONITORING ORGANIZATION REPORT NUMBER(S) } \\
\hline \multicolumn{3}{|c|}{$\begin{array}{l}\text { 6a. NAME OF PERFORMING ORGANIZATION } \\
\text { Geo-Marine Inc. }\end{array}$} & $\begin{array}{l}\text { 6b. OFFICE SYMBOL } \\
\text { (if applicable) }\end{array}$ & \multicolumn{4}{|c|}{$\begin{array}{l}\text { 7a. NAME OF MONITORING ORGANIZATION } \\
\text { US Army Corps of Engineers, Ft. Worth District }\end{array}$} \\
\hline \multicolumn{4}{|c|}{$\begin{array}{l}\text { 6c. ADDRESS (City, State, and Zip Code) I } \\
\qquad 550 \text { E. 15th Street / Plano, Texas / } 75074\end{array}$} & \multicolumn{4}{|c|}{$\begin{array}{l}\text { 7b. ADDRESS (City, State, and Zip Code) } \\
\text { PO Box } 17300 \\
\text { Fort Worth, Texas 76102-0300 }\end{array}$} \\
\hline \multicolumn{3}{|c|}{$\begin{array}{l}\text { 8a. NAME OF FUNDING/SPONSORING } \\
\text { ORGANIZATION } \\
\text { US Army Corps of Engineers, } \\
\text { Ft. Worth District }\end{array}$} & $\begin{array}{l}\text { 8b. OFFICE SYMBOL } \\
\text { (if applicable) } \\
\text { CESWF-PL-RC }\end{array}$ & \multicolumn{4}{|c|}{$\begin{array}{l}\text { 9. PROCUREMENT INSTRUMENT ID NUMBER } \\
\text { DACA63-90-D-0061, Delivery Order Nos. } 083 \text { and } 089\end{array}$} \\
\hline \multicolumn{4}{|c|}{ 8c. ADDRESS (City, State, and Zip Code) } & \multicolumn{4}{|c|}{ 10. SOURCE OF FUNDING NUMBERS } \\
\hline \multicolumn{4}{|c|}{$\begin{array}{l}\text { PO Box } 17300 \\
\text { Fort Worth, Texas } 76102-0300\end{array}$} & $\begin{array}{l}\text { PROGRAM } \\
\text { ELEMENT NO. }\end{array}$ & $\begin{array}{l}\text { PROJECT } \\
\text { NO. }\end{array}$ & $\begin{array}{l}\text { TASK } \\
\text { NO. }\end{array}$ & $\begin{array}{l}\text { WORK UNIT } \\
\text { ACCESSION NO. }\end{array}$ \\
\hline \multicolumn{8}{|c|}{$\begin{array}{l}\text { 11. TITLE (Include Security Classification) } \\
\text { Cultural Resources Survey and Monitoring of Joint Task Force Six (JTF-6) Actions in Webb, Zapata, Dimmit, La Salle, } \\
\text { Duvall, and Jim Hogg Counties, Texas }\end{array}$} \\
\hline \multirow{2}{*}{\multicolumn{8}{|c|}{ 12a. PERSONAL AUTHOR(S) }} \\
\hline & & & & & & & \\
\hline \multicolumn{3}{|c|}{\begin{tabular}{c|c} 
13a. TYPE OF REPORT & 13b. TIME COVERED \\
Final Report & FROM Jan 1993 \\
\end{tabular}} & _TO Jan 1993 & \multicolumn{3}{|c|}{$\begin{array}{l}\text { 14. DATE OF REPORT (Year, Month, Day) } \\
\text { Aug } 1994\end{array}$} & $\begin{array}{l}\text { 15. PAGE COUNT } \\
41\end{array}$ \\
\hline \multicolumn{8}{|c|}{ 16. SUPPLEMENTARY NOTATION } \\
\hline \multicolumn{3}{|c|}{ 17. COSATI CODES } & \multirow{2}{*}{\multicolumn{5}{|c|}{$\begin{array}{l}\text { 18. SUBJECT TERMS (Continue on reverse if necessary and identify by block number) } \\
\text { Cultural resources evaluation and monitoring of areas to be impacted by JTF-6 } \\
\text { actions in and around Laredo, Texas }\end{array}$}} \\
\hline $\begin{array}{c}\text { FIELD } \\
05\end{array}$ & \begin{tabular}{c|} 
GROUP \\
06
\end{tabular} & SUB-GROUP & & & & & \\
\hline \multirow{2}{*}{\multicolumn{8}{|c|}{$\begin{array}{l}\text { 19. ABSTRACT (Continue on reverse if necessary and identify by block number) } \\
\text { As a result of JTF-6 actions representing federal projects in six south Texas counties, cultural resource evaluations and } \\
\text { monitoring were required for the areas that were to be impacted by the construction actions. These actions included the repair } \\
\text { and related construction of approximately } 240 \mathrm{~km} \text { of existing firebreaks along highways in the six-county area, the upgrade of } \\
\text { two small-arms firing ranges, the repair/upgrade of } 9.5 \mathrm{~km} \text { of road along the Rio Grande, and the construction of a } \\
\text { fitness/obstacle course and the upgrade of an existing firing range in Laredo. } \\
\text { All areas were intensively surveyed and monitored for evidence of prehistoric and historic cultural resources, with areas of high } \\
\text { probability closely examined. Extensive previous disturbance was noted within the impact areas of the firebreaks and at the two } \\
\text { firing ranges, but no cultural resources were located in these areas. Along the Rio Grande, the survey identified Star Fort (part } \\
\text { of historic Fort Mclntosh), which was crossed by the road improvement project, and the San Ygnacio Historic District. These } \\
\text { sites are listed on the National Register and were avoided except for the grading of an existing road adjacent to the remains of } \\
\text { Star Fort (which resulted in no damage to the historic property). The proposed fitness/obstacle course is located within an old } \\
\text { industrial area that has been previously determined to lack significant cultural resources. Therefore, the road } \\
\text { improvement/construction activities of the JTF-6 action resulted in no impacts to the cultural resources of the areas. }\end{array}$}} \\
\hline & & & & & & & \\
\hline \multicolumn{4}{|c|}{$\begin{array}{l}\text { 20. DISTRIBUTION/AVAILABILITY OF ABSTRACT } \\
\square \text { UNCLASSIFIED/UNLIMITED } \text { \SAME AS }\end{array}$} & \multicolumn{4}{|c|}{$\begin{array}{l}\text { 21. ABSTRACT SECURITY CLASSIFICATION } \\
\text { Unclassified }\end{array}$} \\
\hline \multicolumn{4}{|c|}{$\begin{array}{l}\text { 22a. NAME OF RESPONSIBLE INDIVIDUAL } \\
\text { Jay R. Newman }\end{array}$} & \multicolumn{3}{|c|}{$\begin{array}{r}\text { 22b. TELEPHONE (Include Area C } \\
817-334-2625\end{array}$} & $\begin{array}{l}\text { 22c. OFFICE SYMBOL } \\
\text { CESWF-PL-RC }\end{array}$ \\
\hline
\end{tabular}





\title{
CULTURAL RESOURCES SURVEY AND MONITORING OF JOINT TASK FORCE SIX (JTF-6) ACTIONS IN WEBB, ZAPATA, DIMMIT, LA SALLE, DUVALL, AND JIM HOGG COUNTIES, TEXAS
}

\author{
by \\ Stephen P. Austin \\ Scott Ferguson \\ Steven M. Hunt \\ Floyd B. Largent, Jr. \\ Mark A. Sale \\ Principal Investigator: \\ Duane E. Peter

\begin{abstract}
for
U.S. Army Corps of Engineers

Fort Worth District

Contract No. DACA63-90-D-0061

Delivery Order Nos. 083 and 089
\end{abstract}

Miscellaneous Report of Investigations No. 63

Geo-Marine, Inc.

550 East 15th Street

Plano, Texas 75074 


\section{CONTRACT DATA}

The preparation of this document was accomplished under Contract Number DACA63-90-D-0061, Delivery

Order Nos. 083 and 089 (GMI project Nos. 1161-083 and 1161-089) with the U.S. Army Corps of Engineers, Fort Worth District, P.O. Box 17300, Fort Worth, Texas 76102-0300. 


\section{MANAGEMENT SUMMARY}

Joint Task Force Six (JTF-6) Operation AT-93 involved multiple actions in six south Texas counties. These actions included the repair and construction of approximately $240 \mathrm{~km}(150 \mathrm{mi})$ of existing firebreaks, the repair/upgrade of approximately $9.5 \mathrm{~km}(5.9 \mathrm{mi})$ of road along the Rio Grande River near Laredo, the upgrade of two small-arms firing ranges, and the construction of a fitness/obstacle course. Extensive previous disturbance was noted within the impact areas of the firebreaks and at the two firing ranges; no cultural resource sites were located in these areas.

Along the Rio Grande, the survey identified the site of Star Fort (part of historic Fort McIntosh), which was crossed by the road improvement project. The proposed fitness/obstacle course is located within an old industrial area, which has been previously determined to lack significant cultural resources. The sites of Star Fort and the San Ygnacio Historic District were recognized as National Register properties that needed to be avoided. Avoidance of these properties was successful except for the grading of an existing road adjacent to the remains of Star Fort that had been marked for avoidance. Fortunately, this action resulted in no damage to the historic property. In summary, Operation AT-93 resulted in no impacts to the cultural resources of the region. 



\section{TABLE OF CONTENTS}

MANAGEMENT SUMMARY $\ldots \ldots \ldots \ldots \ldots \ldots \ldots \ldots \ldots \ldots \ldots \ldots$ iii

ACKNOWLEDGEMENTS $\ldots \ldots \ldots \ldots \ldots \ldots \ldots \ldots \ldots \ldots \ldots \ldots \ldots \ldots \ldots \ldots$

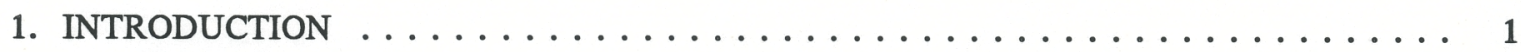

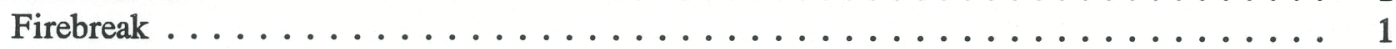

Rio Grande . . . . . . . . . . . . . . . . . . . 5

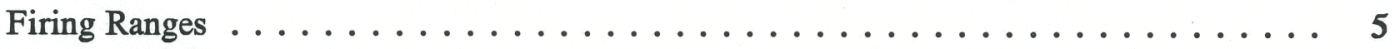

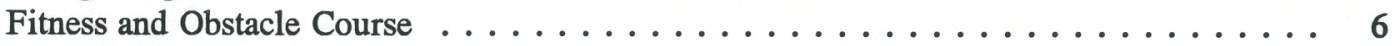

2. ENVIRONMENTAL AND CULTURAL OVERVIEWS $\ldots \ldots \ldots \ldots \ldots \ldots \ldots$

Environment Setting . . . . . . . . . . . . . . . . . . 9

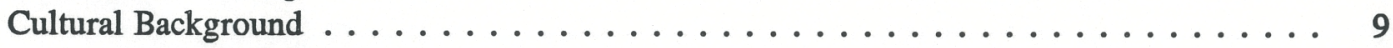

Introduction . . . . . . . . . . . . . . . . . . 9

Previous Research in Southern Texas . . . . . . . . . . . . . . 10

Previous Research in the Project Area . . . . . . . . . . . . . . . 10

Rio Grande Road . . . . . . . . . . . . . . . 11

Fitness and Obstacle Course ................ 11

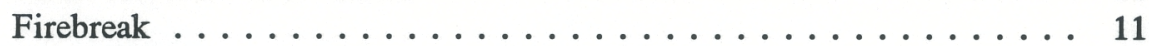

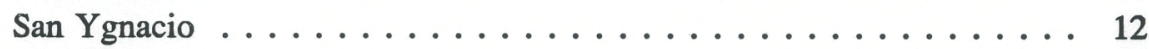

Fort McIntosh ................... 13

Star Fort ...................... 14

Cultural Chronology in Southern Texas . . . . . . . . . . . . . 14

Prehistoric ...................... 14

Paleo-Indian . . . . . . . . . . . . . . 14

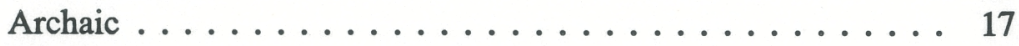

Late Prehistoric ................... 21

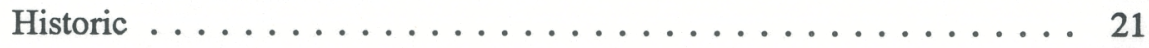

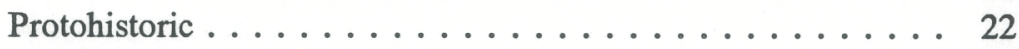

Spanish Colonial ................... 22

Mexican-Texas-American ................ 23

3. METHODOLOGY ............................ 25

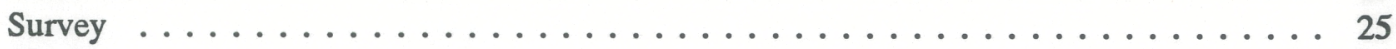

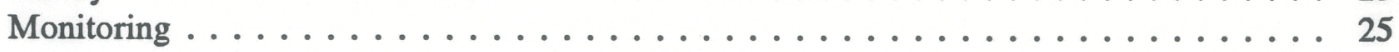

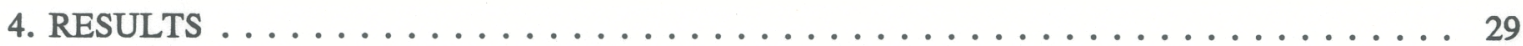

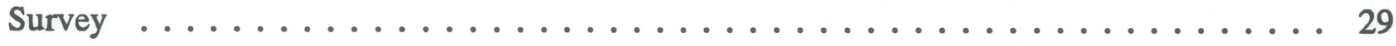

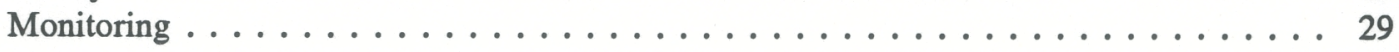


Table of Contents

(cont'd)

5. SUMMARY AND RECOMMENDATIONS $\ldots \ldots \ldots \ldots \ldots \ldots \ldots \ldots \ldots \ldots$

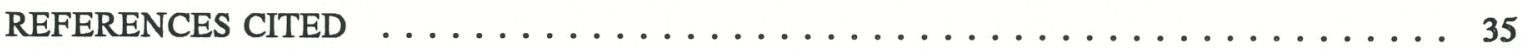




\section{LIST OF FIGURES}

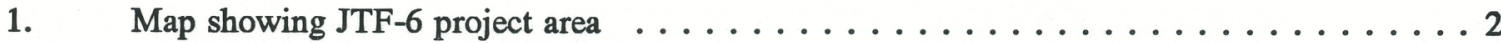

2. Map showing the location of the firebreaks and firing ranges. . . . . . . . . 3

3. Map showing the location of the River Road and the fitness and obstacle course. . . . . 4

4. U.S.G.S. quad map showing the location of the fitness and obstacle course and its relation to Fort McIntosh. . . . . . . . . . . . . . . . . 7

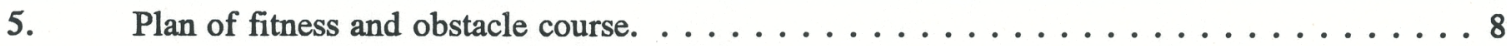

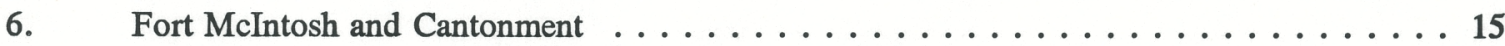

7. Diagnostic projectile points of the Paleo-Indian period of South Texas: (a) Clovis;

(b) Folsom; (c) Golondrina; (d) Scottsbluff; and (e) Angostura . . . . . . . . . . . . . 16

8. Diagnostic projectile points of the Early Archaic period of South Texas: (a) Bell;

(b) Andice; (c)Early Triangular; (d) Bandy; (e) Martindale; and (f) Uvalde . . . . . . . 18

9. Diagnostic projectile points of the Middle Archaic period of South Texas:

(a) Pedernales; (b) Langtry; (c) Kinney; (d) Bulverde; and (e) Tortugas . . . . . . . . . 19

10. Diagnostic projectile points of the Late Archaic period of South Texas: (a) Ensor;

(b) Frio; (c) Marcos; (d) Fairland; and (e) Ellis . . . . . . . . . . . . . . . 20

11. Diagnostic projectile points of the Late Prehistoric period of South Texas:

(a) Scallorn; (b) Toyah . . . . . . . . . . . . . . . . . . . . . 21

12. Location of new construction areas surveyed during monitoring $\ldots \ldots \ldots \ldots$ 



\section{ACKNOWLEDGEMENTS}

The authors would like to express their appreciation to the individuals who contributed to the successful completion of the project documented in this report. Jay R. Newman (JTF-6 project archeologist) and Eric Verwers (JTF-6 project biologist) at the U.S. Army Corps of Engineers, Fort Worth District; the U.S. Border Patrol; the National Guard; and Joint Task Force 6 were supportive of our efforts and provided both administrative support and guidance. In the field, the efforts of the crew members, including Ms. Carolyn Barnes, Mr. Scott Ferguson, and Mr. Mark Sale, were essential to the successful completion of the fieldwork.

Drafting of the figures was performed by Ms. Sandra Carr and Mr. Shane Watson. The formatting of the report was performed by Ms. Denise Pemberton and Ms. Rebecca Procter. Ms. Sharlene Allday was responsible for the technical editing and the overall production of this report. 



\section{INTRODUCTION}

The Joint Task Force Six (JTF-6) Operation AT-93 involved four separate actions in six south Texas counties. Since these actions represented Federal projects with the potential for damaging or destroying cultural resources, JTF- 6 was required to conduct a cultural resources evaluation of the proposed impact areas, in order to be in compliance with Section 106 of the National Historic Preservation Act (NHPA) of 1966 [P.L. 89-665; 80 Stat. 915; 16 U.S.C. $\S 470$ et seq.]; the Archeological and Historic Preservation Act of 1974 (AHPA) [P.L. 93-291; 88 Stat. 174; 16 U.S.C. $\$ 469$ et seq.]; the National Environmental Policy Act of 1969 [P.L. 91-190; 83 Stat. 852; 42 U.S.C $\$ 4221$ et seq.]; American Indian Religious Freedom Act of 1978 (AIRFA) [P.L. 92; Stat. 469; 42 USC § 1996]; Native American Graves Protection and Repatriation Act (NAGPRA) [P.L. 101-601; 104 Stat. 3048; 25 USC § 3001 et seq.]; and Executive Order Number 11593, "Protection and Enhancement of the Cultural Environment."

The impacted areas lie principally within Webb, Zapata, Dimmit, La Salle, Duvall, and Jim Hogg counties (Figure 1). These actions included (1) the repair and related construction of approximately $240 \mathrm{~km}(150$ $\mathrm{mi}$ ) of existing firebreaks along highway rights-of-way (Sections B, C, D, E, H, J, M, and N in Figure 2); (2) the upgrade of two small-arms firing ranges near Freer and Hebbronville (Sections F and L in Figure 2); (3) the repair/upgrade of approximately $9.5 \mathrm{~km}(5.9 \mathrm{mi})$ of road along the Rio Grande in and near Laredo (Section A in Figure 3); and (4) the construction of a fitness/obstacle course and upgrades to an existing firing range in Laredo (Figure 3). Each area and its associated impact are described below.

\section{FIREBREAK}

The existing firebreaks were regraded in order to remove encroaching vegetation and to repair eroded areas. Approximately $2.5 \mathrm{~m}(8 \mathrm{ft})$ of each fire break was regraded; in addition, new construction of approximately $1.6 \mathrm{~km}(1 \mathrm{mi})$ of new firebreak was required in eight areas. Descriptions of the individual construction locations are as follows (USACOE 1993):

- Section "B" is located on Farm-to-Market (FM) road 3338 in Webb County; it begins at the intersection of FM 3338 and FM 1472, and continues along both sides of FM 3338 for approximately eight miles (16 miles $[25.6 \mathrm{~km}]$ total) to the end of the pavement.

- Section "C" lies on Interstate (I) 35 in Webb County, starting at the intersection of I-35 and Highway 83 and continuing south along both sides of the interstate for a distance of $2 \mathrm{mi}(4 \mathrm{mi}$ [6.4 km] total). The southbound side falls between the frontage road and fenceline; the northbound side lies between the frontage road and railroad.

- Section " $\mathrm{D}$ " is located along the railroad in Webb County, beginning at the 22-mile-mark of I-35 and continuing north along both sides of the railroad track for $2 \mathrm{mi}(4 \mathrm{mi}[6.4 \mathrm{~km}]$ total). 


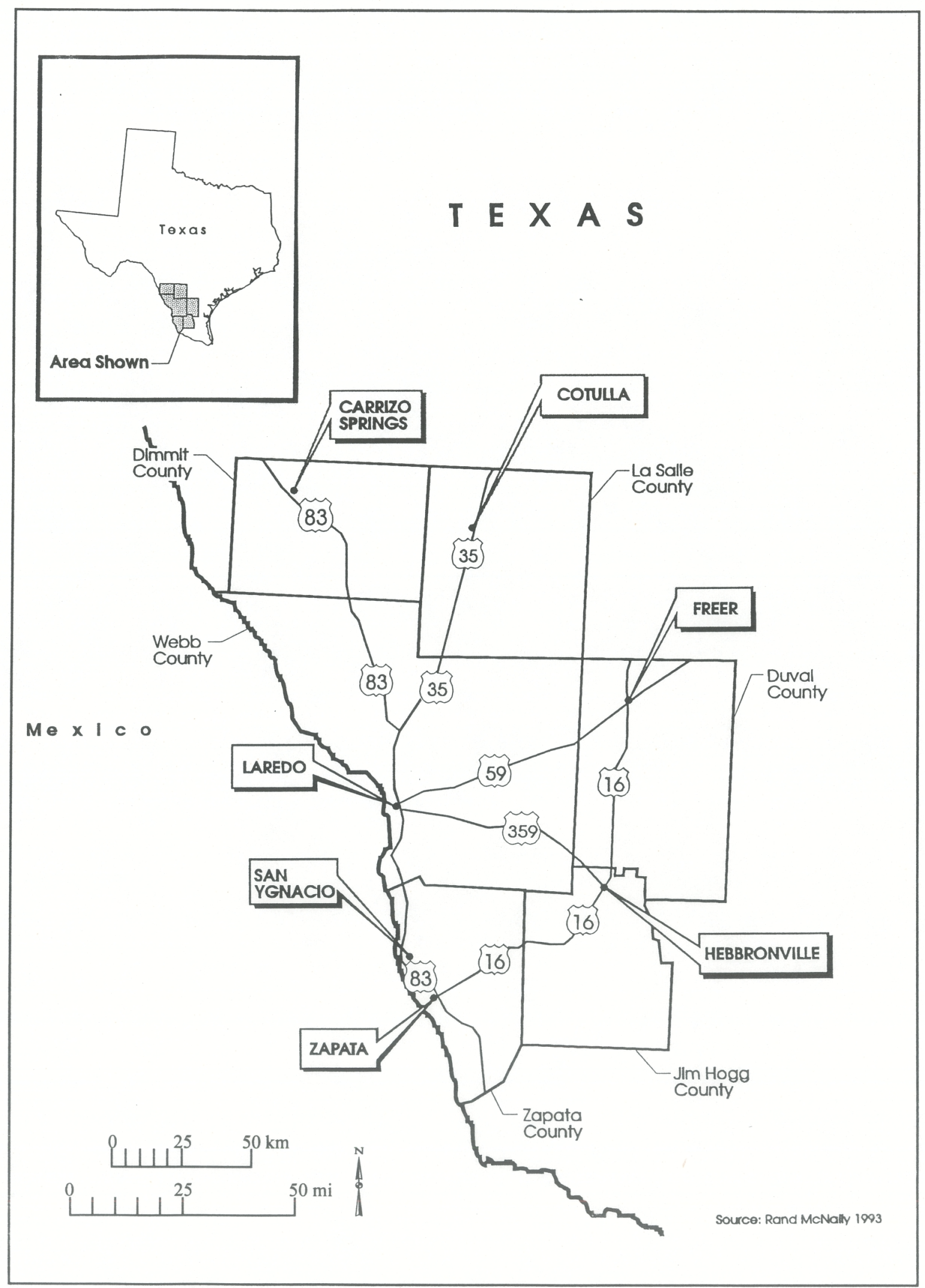

Figure 1. Map showing JTF-6 project area (Source: Rand McNally 1993). 


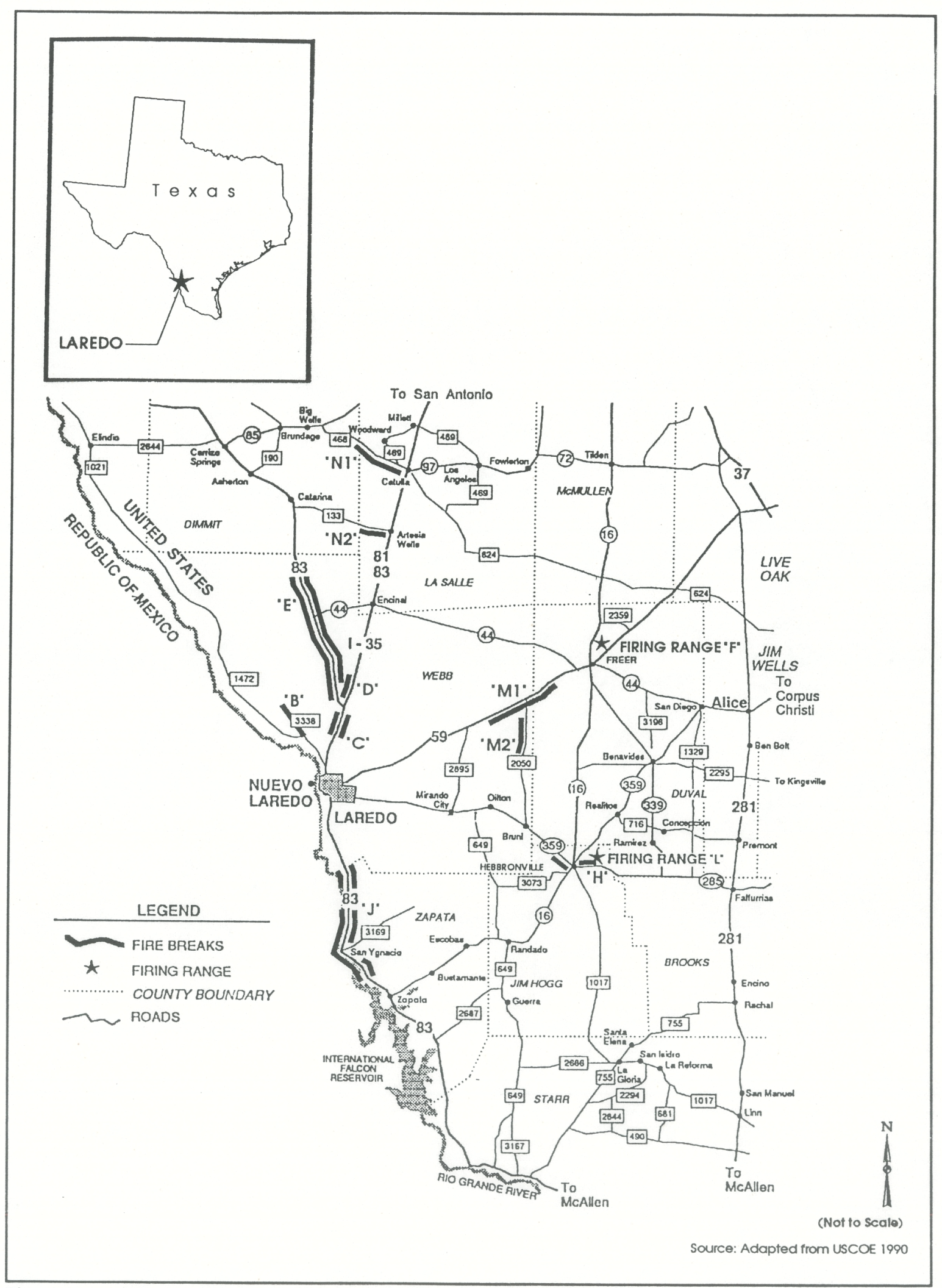

Figure 2. Map showing the location of the firebreaks and firing ranges (Source: Adapted from USACOE 1990). 


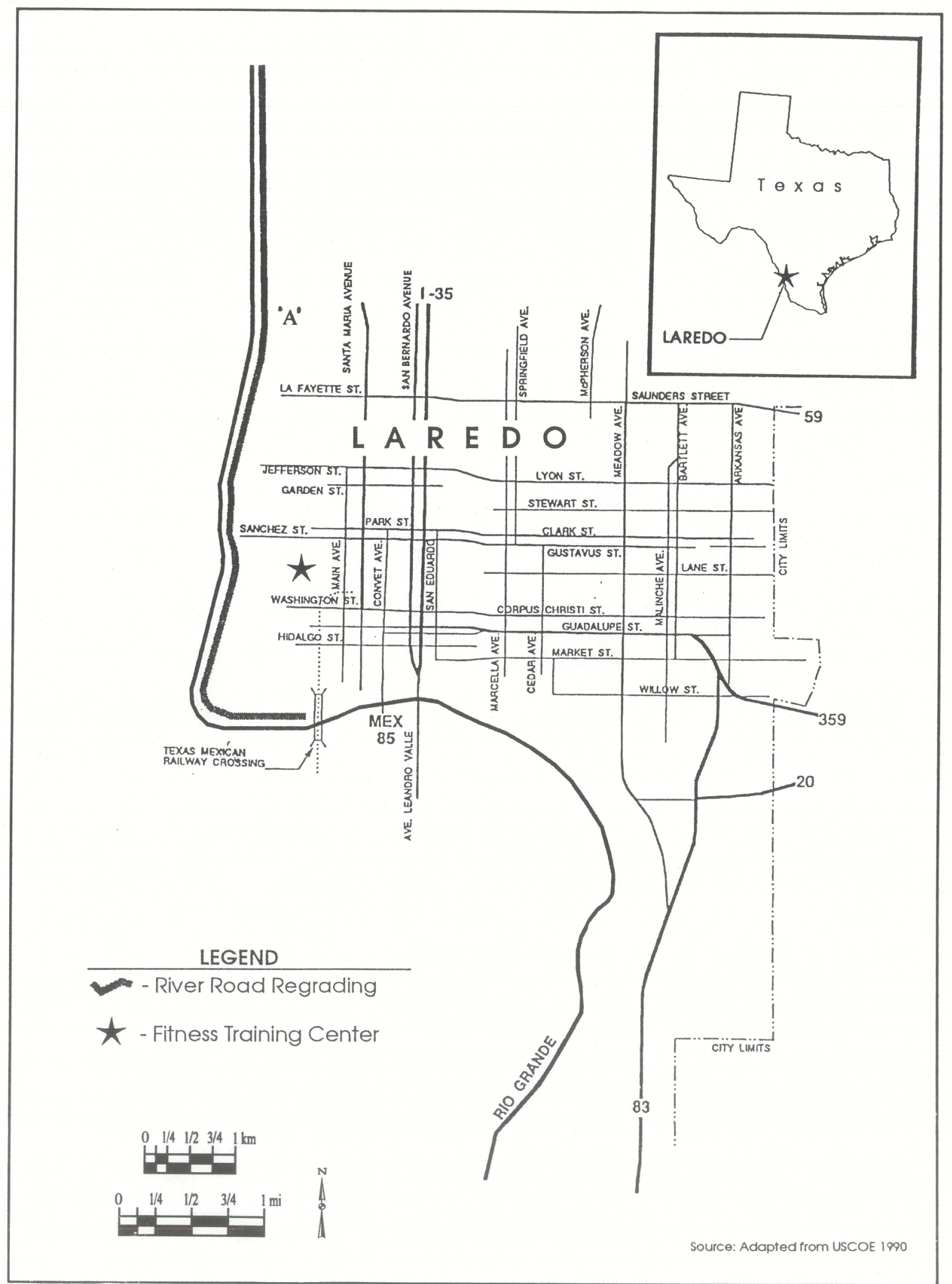

Figure 3. Map showing the location of the River Road and the fitness and obstacle course (Source: Adapted from USACOE 1990). 
- Section " $E$ " falls along Highway 83 in Webb County, starting at the intersection of Highway 83 and I-35 and continuing northwest along both sides of Highway 83 for $26 \mathrm{mi}(52 \mathrm{mi}$ [83.2 km] total).

- Section "H" lies along railroad rights-of-way at two locations in Jim Hogg County. Section "H1" starts at the second road crossing west of Hebbronville and continues west along both sides of the railroad track for $1 \mathrm{mi}(2 \mathrm{mi}[3.2 \mathrm{~km}]$ total). Section "H2" starts at the Randado crossing and continues east along both sides of the railroad track approximately $2 \mathrm{mi}(4$ miles $[6.4 \mathrm{~km}]$ total) to the trestle.

- Section "J" is situated along Highway 83 in Zapata County, starting three miles south of the Zapata/Webb county line and continuing south along both sides of Highway 83 for approximately $21 \mathrm{mi}(42 \mathrm{mi}[67.2 \mathrm{~km}]$ total), to the last rest stop before the town of Zapata.

- Section " $L$ " is located in La Salle County. This section starts on the south side of the intersection of FM 133 and I-35 and extends $12 \mathrm{mi}$ [19.2 km] west, ending near the La Salle/Dimmit county line.

- Section "M" falls along two sections of roadway in Webb and Duvall counties. Section "M1" is located along Highway 59 , starting $5 \mathrm{mi}(8 \mathrm{~km})$ east of the USBP checkpoint and continuing west along the south side of the highway for $10 \mathrm{mi}(16 \mathrm{~km})$. Section "M2" falls along FM 2050, starting at the intersection of FM 2050 and Highway 59 and continuing south along the west side of FM 2050 for $10 \mathrm{mi}(16 \mathrm{~km})$.

- Section "N" is located along the south side of FM 468, starting at the intersection of FM 468 and I-35 and continuing west for $15 \mathrm{mi}(24 \mathrm{~km})$.

\section{RIO GRANDE}

This action (Section "G") began at the international railroad bridge in Laredo (Webb County) and continued north along the river terrace. The majority of this action consisted of upgrading the existing road or trail to an approximate width of $2.5 \mathrm{~m}(8 \mathrm{ft})$. The total length of this section is approximately 5.9 miles $(9.44$ $\mathrm{km})$. Although the entire length of Section $\mathrm{G}$ had been previously disturbed, eight small portions of this route totaling less than $1 \mathrm{mi}(1.6 \mathrm{~km})$ were overgrown with vegetation at the time of the survey.

\section{FIRING RANGES}

This action involved the upgrading of two existing small-arms firing ranges. The first range, Firing Range $\mathrm{L}$, is located near the town of Hebbronville (Jim Hogg County) on the north side of Texas Highway 285, $1.4 \mathrm{mi}(2.2 \mathrm{~km})$ east of Texas Highway 1017. Construction at the Hebbronville firing range involved the erection of a $3 \times 3-\mathrm{m}(10 \times 10 \mathrm{ft})$ concrete pad for a building, a $4 \times 6-\mathrm{m}(12 \times 20 \mathrm{ft})$ awning, walkways and target stands. The existing berm, which was originally upgraded by JTF- 6 in 1990, was reshaped and expanded from $6 \mathrm{~m}(20 \mathrm{ft})$ to $21 \mathrm{~m}(70 \mathrm{ft})$ in length.

The second range (Firing Range F) is located near the town of Freer (Duvall County) on the east side of Texas Highway 16, $2.3 \mathrm{mi}(3.7 \mathrm{~km})$ north of the intersection of Highway 16 and Highway 59. The 10-ac site containing this firing range originally supported two ranges, both of which included an existing dirt road and earthen berm. The southernmost of the two sites is located adjacent to Highway 16, and was not suitable for upgrade due to safety reasons; in addition, the site was not long enough to allow for sniper 
qualification. The northern site was located farther from the highway and was longer than the southern site; therefore, it was the preferred construction area. Improvements included clearing and grubbing the dirt road to approximately $30 \times 91 \mathrm{~m}(100 \times 300 \mathrm{ft})$. The existing berm was reshaped and expanded from approximately $6 \mathrm{~m}(20 \mathrm{ft})$ to $21 \mathrm{~m}(70 \mathrm{ft})$ in length.

\section{FITNESS AND OBSTACLE COURSE}

A fitness/obstacle course (Section "A") was constructed on Laredo Junior College (LIC) property near the former location of Fort McIntosh (Figure 4). This area is also the site of an existing railroad loading dock and firing range. Construction of the fitness/obstacle course involved clearing and grubbing a rectangular area $99 \mathrm{~m}$ wide by $480 \mathrm{~m}$ long ( $327 \times 1584 \mathrm{ft}$ ). A fitness trail, drill pavilion, obstacle course, rappel tower, parking lot, softball field backstop, and associated security fencing were constructed on the site (Figure 5). Star Fort and other portions of Fort McIntosh were avoided during the course of the construction work.

The cultural resource investigations of these areas were conducted by personnel from Geo-Marine, Inc., of Plano, Texas, during the first part of 1993 under Contract Number DACA63-90-D-0061, Delivery Order No. 083, with the U.S. Army Corps of Engineers, Fort Worth District, Fort Worth, Texas. The field investigations were conducted by Mr. Mark H. Sale and Ms. Carolyn P. Barnes. The monitoring was accomplished by Mr. Scott Ferguson under Delivery Order No. 089 of the same contract. All areas were intensively surveyed for evidence of prehistoric and historic cultural resources. Areas of high probability for site occurrence were closely examined. The methodology used for each survey area was similar, and is presented in the appropriate section. The following sections of the report present an environmental and cultural overview of the project areas, a discussion of previous cultural resource investigations and significant sites, a discussion of the survey methodology used, the survey results, and recommendations. 


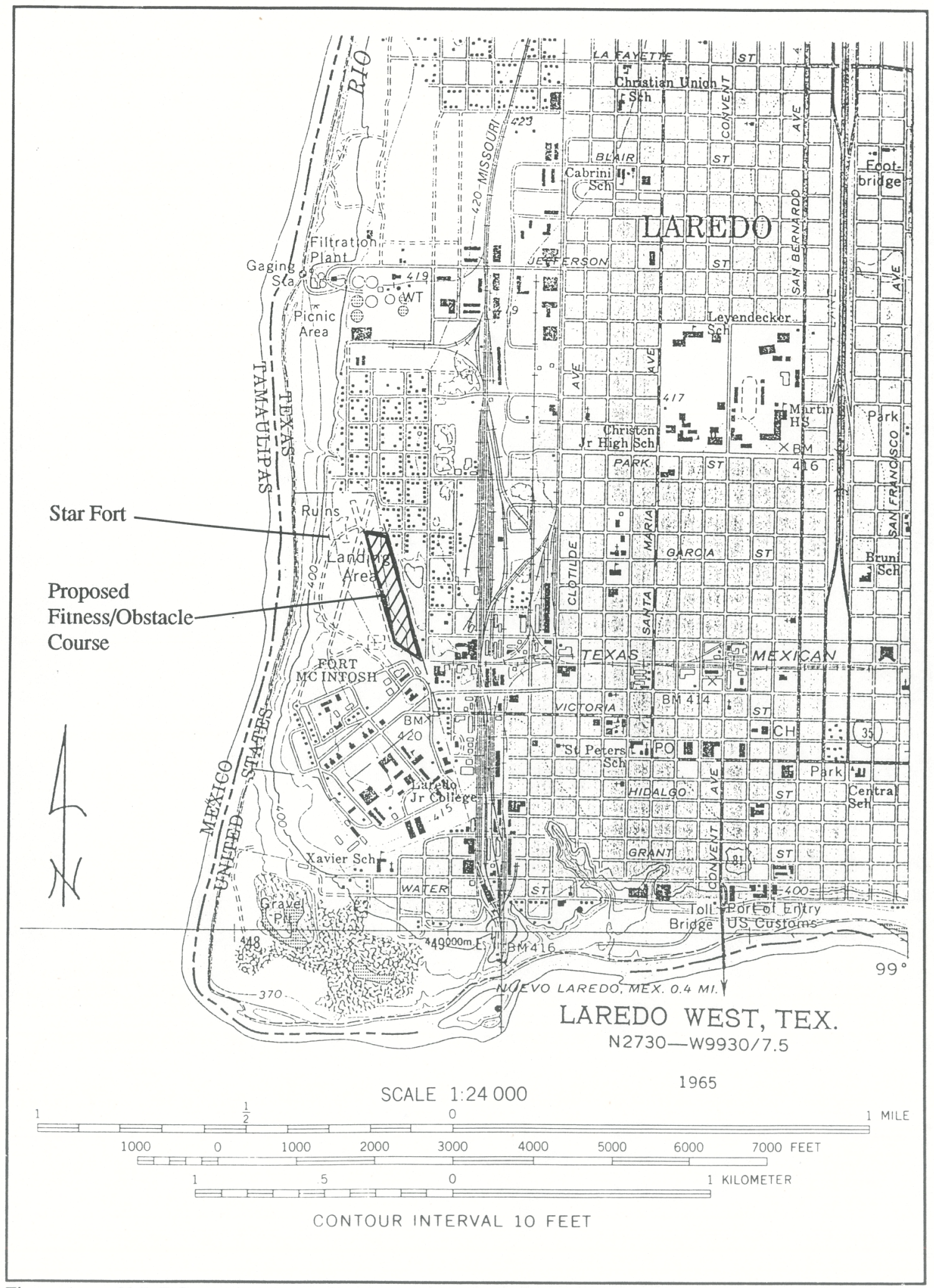

Figure 4. U.S.G.S. quad map showing the location of the fitness and obstacle course and its relation to Fort McIntosh. 


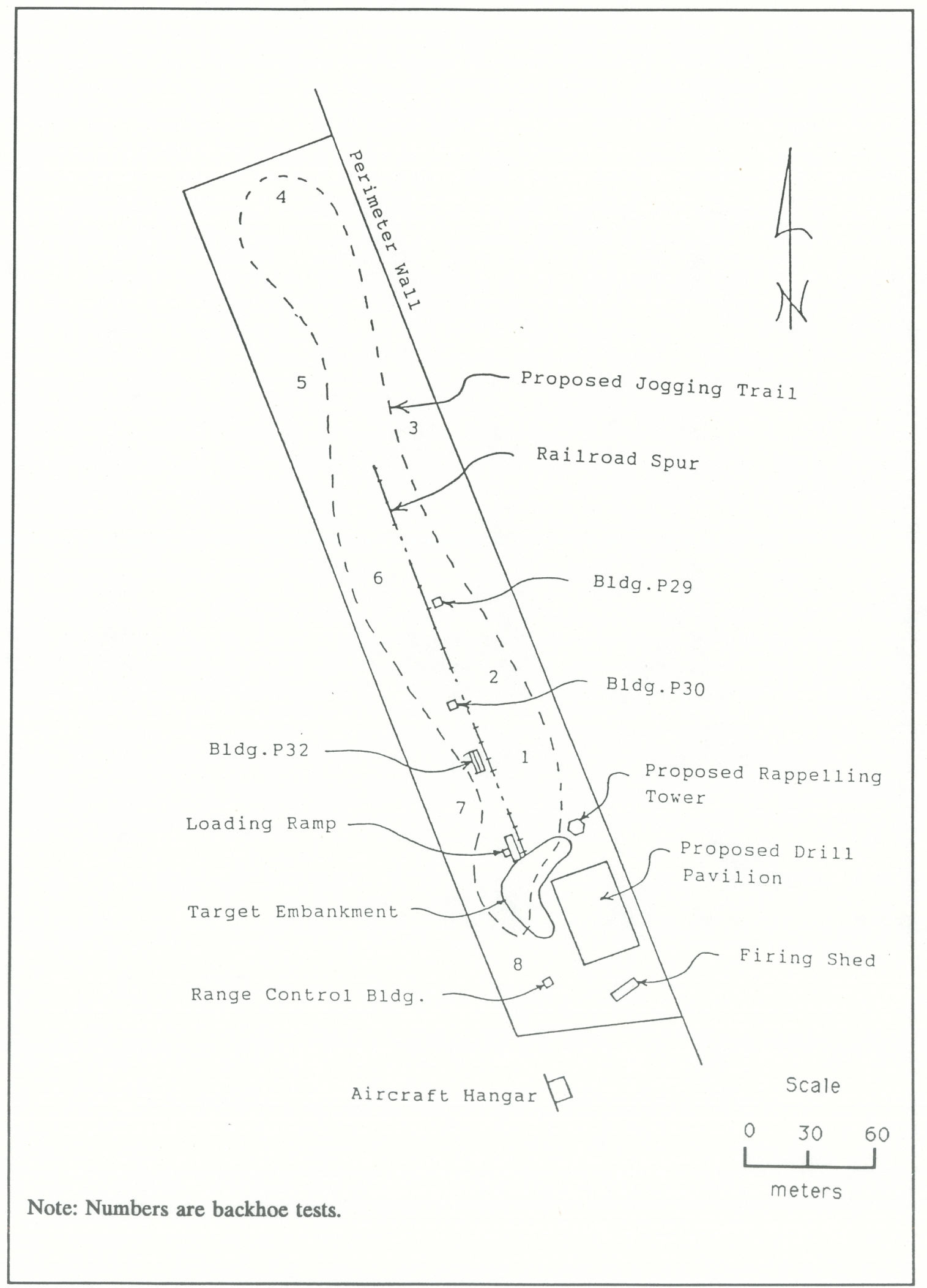

Figure 5. Plan of fitness and obstacle course. 


\section{ENVIRONMENTAL AND CULTURAL OVERVIEWS}

\section{ENVIRONMENT SETTING}

Geologically, the project area is contained within the West Gulf Coastal Plains section of the Coastal Plains province. The surface consists of consolidated and unconsolidated sedimentary and eolian deposits. The sedimentary deposits range in age from the Holocene to the Eocene, while the eolian deposits are Holocene and Pleistocene in origin. While the parent materials of the soils have a great impact upon their composition, the low rainfall and high evaporation rates characteristic of the region have led to the retention and accumulation of calcium carbonate and soluble salts in the soil, which tends to enhance similarity in the soils despite differences in age and makeup (Sanders and Gabriel 1985:90-92).

The biogeography of project area is subsumed within Blair's (1950) Tamaulipan province, which extends from eastern Mexico into southern Texas. The climate of the Tamaulipan province is semiarid and megathermal, with a moisture deficiency index of -20 to -40 percent. Summers in the region are hot, while winters are relatively mild. Snow is rare, only occurring in 15 percent of the winters. Annual precipitation is approximately 20 in $(51 \mathrm{~cm})$, with the majority occurring in late spring and early fall. The rate of evapotranspiration is high (Sanders and Gabriel 1985:3).

Plant growth continues throughout the year, and thorny brush dominates the vegetation of this region. The most important species include mesquite, lignum vitae, cenizo, white brush, prickly pear, tasajilo, Acacia, Mimosa, Condalia, and Castela. The vertebrate fauna in the region is composed mainly of Neotropical animals (lower Rio Grande Valley) with smaller amounts of Sonoran (arid Southwest) and Austroriparian (Eastern Woodlands) species (Blair 1950:95). Animals presently found within the region include deer, javelina, rabbit, squirrel, coyote, cougar, duck, quail, dove, geese, roadrunner, rattlesnake, Texas tortoise, and horned lizard (Sanders and Gabriel 1985:54-55).

\section{CULTURAL BACKGROUND}

\section{Introduction}

The project area is a part of the South Texas archeological region (Hester et al. 1989). This region extends from the Edwards Plateau to the Gulf of Mexico and southward into northern Mexico. It is located entirely within the Tamaulipan biotic province (Hester 1989a:3). The five subdivisions that have been recognized within this region are: (1) Rio Grande Plain, (2) Rio Grande Delta, (3) Nueces-Guadalupe Plain, (4) Sand Sheet, and (5) Coastal Bend (Black 1989:39). Most of the study areas are found primarily within the Rio Grande Plain, while the remaining areas lie within the Nueces-Guadalupe Plain. The Rio Grande Plain contains a narrow band paralleling and draining into the Rio Grande. Reliable water sources in this region are rare away from the Rio Grande. The Nueces-Guadalupe Plain is the largest subarea of south Texas 
and is characterized by southeastward flowing streams that divide the region into narrow bands of riparian vegetation along streams and broad areas of grassy and thorny savanna (Black 1989:39-40).

In general, the archeology of South Texas shows great similarities with the surrounding regions of Central Texas and the Trans-Pecos, but also shares common traits (especially the Rio Grande Plain subregion) with adjacent parts of Mexico. Unfortunately, these parts of Mexico are less well-known archeologically than South Texas. A number of recent reviews on the archeology of South Texas have been published (Black 1986; Carlson et al. 1982; Hall et al. 1982:7-23; Hester 1980; Highley 1986; Mallouf et al. 1977; Shafer and Bond 1985; Usrey 1980). The following discussions are based primarily on Black's (1989) most recent archeological synthesis for South Texas.

\section{Previous Research in Southern Texas}

The earliest archeological investigations in south Texas were conducted by avocational archeologists along the Gulf Coast (Anderson 1932; Mallouf et al. 1977:57-59; Martin 1929, 1930a, 1930b, 1931; Martin and Potter n.d.; Potter 1930). Professional interest in South Texas began in 1935, when E.B. Sayles, an archeologist with the Gila Pueblo Foundation, produced an archeological synthesis that included South Texas. While Sayles' research focus (i.e., a search for the origin of Southwestern peoples and pottery) was unsuccessful, his perceptions of the archeology in South Texas form the basic chronological framework of the region. Typological studies of artifacts also began in this period (Jackson 1940; Patterson 1936; Poteet 1938). From the late 1930s, a number of significant sites in South Texas were excavated, including Buckner Ranch (Sellards 1940), Johnson (Campbell 1947), Kent-Crane (Campbell 1952), Live Oak Point (Campbell 1958), and Ayala (Campbell and Frizzell 1949). These sites, together with MacNeish's (1947, 1958) investigations in northern Tamaulipas and adjacent portions of Texas, were also important in defining the archeology of the region.

Beginning in the 1950s, the pace of archeological research increased as a result of planned reservoir projects that were to impact many of the larger drainage basins in the region. For example, construction of the Falcon Reservoir brought investigations under the auspices of the River Basin Survey (Cason 1952; Hartle and Stephenson 1951; Jelks 1952, 1953; Kreiger n.d.; Kreiger and Hughes 1950). Many other investigations were also conducted during this time along the coast (Campbell 1956, 1962; Corbin 1963; Fitzpatrick et al. 1964; Hester 1968b, 1969; Story 1968), the Rio Grande Delta, (Hester et al. 1969), and the inland region (Hester 1968a,b,c; Hester and Hill 1969; Hester et al. 1969; Nunley and Hester 1966; Wakefield 1968). Since the 1970s, the majority of archeological projects in South Texas have been conducted through cultural resource management (CRM) programs as a result of legislative actions requiring systematic recording and preservation of endangered historic places and archeological sites. Major CRM projects in South Texas include investigations at Choke Canyon (Hall et al. 1982; Highley 1986; Lynn et al. 1977; Wakefield 1968), Cuero I (Fox 1974), and Coleto Creek (Brown 1983; Fox 1979; Fox and Hester 1976; Fox et al. 1979).

Previous Research in the Project Area

Projects conducted with greater relevance to the study areas include several surveys along the Rio Grande (Fox and Vecker 1977; McGraw 1983; USACOE 1990), previous investigations of the impacted fitness/obstacle course (Warren 1991), and investigations of Star Fort and Fort McIntosh (Briggs 1982; Warren 1987, 1991). 


\section{Rio Grande Road}

The northern segment of the river frontage project area (north of Jefferson Street) was previously surveyed for cultural resources by Fox and Vecker in 1977, and the remaining portions of this proposed route were inspected by a U.S. Army Corps of Engineers archeologist in 1990 (USACOE 1990). No cultural resources were located during these previous investigations.

\section{Fitness and Obstacle Course}

The fitness/obstacle course is located approximately $200 \mathrm{~m}$ north and east of the main section of Fort McIntosh. The proposed fitness/obstacle course is located on the Laredo Junior College campus, and encompasses several existing structures. Archival research and recording of these buildings was conducted in 1991 (Warren 1991). In addition to this documentation, eight randomly spaced backhoe trenches were excavated within the proposed construction area. No cultural debris pre-dating World War II was located during this investigation. Based on these findings, Warren (1991:12) concluded that the area proposed for construction of the fitness/obstacle course had been minimally used during the early period at Fort McIntosh. As the construction plans did not include impacts on existing structural remains, Warren (1991:12) recommended that the project proceed.

\section{Firebreak}

The work along firebreak sections was limited to road maintenance and removal of grass cover within existing road and railroad right-of-ways. Without exception, all archeological sites within these areas demonstrate previous blading disturbance sufficient to remove most, if not all, cultural debris from within the right-of ways. The few remaining artifacts observed consist of displaced lithic debris mixed with flakes created by bulldozer impacts upon naturally occurring chert cobbles. Private property fencelines bordering the firebreak rights-of-way inhibit inspection of remaining cultural debris outside the bladed "zone." This situation, combined with often scanty site records and an overall scarcity of published reports, precludes an in-depth, site-by-site discussion. In light of this scenario, a rather general discussion of site types on record within the proposed project area is appropriate.

Two general types of archeological sites are prevalent along the proposed routes: prehistoric lithic scatters and nineteenth century colonial structures. The former most often occur within elevated areas or along major drainages. Such locations may include ground stone tools and fire-hearth remnants likely representing base camps. Projectile points documented on these strategically placed lithic scatters frequently include both early and late styles, suggesting periodic usage over a considerable span of time. Other, generally smaller lithic scatter sites occur almost randomly throughout the countryside. These smaller examples seldom include hearths or ground stone tools, and typically do not exhibit the variety of projectile points. This site type probably represents limited activities or task-specific locations. In areas where these sites are found, natural chert cobbles are either present or occur nearby, providing a source for lithic raw materials. The majority of the sites most likely represent single-episode butchering or lithic quarry/reduction locations. Previously recorded sites exhibited lithic materials including stone tools. These tools are considered typical of hunter-gatherer stone tool assemblages and are representative of Archaic-style subsistence strategies. A preponderance of hunter-gatherer sites is not surprising in an area so rich in vegetation, game, and riverine resources.

A recent survey conducted for the proposed Camino Colombia Toll Road resulted in the recording of numerous prehistoric sites (Texas Archeological Research Laboratory [TARL] files). Two of these sites (41WB295 and 41WB300) are located in the vicinity of the impacted areas. Only site 41WB295, however, is in the area of potential effect. This Late Archaic to Late Prehistoric site was originally impacted by the 
construction of Highway 83. All that remains is a low density surficial scatter of lithic debris and tools. The site was determined to have no research potential, and it was deemed ineligible for inclusion in the National Register of Historic Places. Site 41WB300, located to the north of the proposed impact area along Interstate Highway 35, is a similar low density lithic scatter that has also been determined to be ineligible for inclusion in the National Register of Historic Places.

Another previously recorded site that lies within the impacted area in Section "B" is site 41WB214, located at the intersection of FM 1472 and FM 3338. This prehistoric lithic scatter was recorded prior to the widening of FM 1472, and is also a surficial lithic scatter that was determined to be ineligible for inclusion in the National Register of Historic Places.

Two sites (41ZP149 and 41ZP150) were previously recorded within Section "J" in Zapata County. Site $41 \mathrm{ZP} 149$ is a surficial lithic scatter that had been previously impacted by the construction of Highway 83 and the grading of the drag road in the highway right-of-way. This site is located on the opposite side of the road and was not impacted by the proposed action. No evidence of site 41ZP150 was found at its plotted location.

Prehistoric sites that include burials have been located and investigated along the upper terrace of the Rio Grande riverbank, just south of Laredo (McGraw 1983). Though none of these sites have been located in the current proposed project area, these documented sites have typically been deeply buried by silt deposits and recognized only in erosional cuts.

Historic structures comprise the other major group of known sites located in the study area. Spanish colonization of southwest Texas formally began in the mid-eighteenth century when the proposed project area was still part of New Spain. To encourage settlement, Spain was readily granting lands along the Rio Grande in southwest Texas by 1750 . Under the conditions of these grants, houses were to be constructed within two years (Folan et al. 1986), which undoubtedly contributed to the rapid appearance of stone structures along the river and its tributaries, leading to the founding of the town of Laredo in 1755 . By 1789 the Laredo census listed 800 residents, 700 of whom were of Spanish descent. Population expansion marked by Spanish-influenced architecture continued through the 1800s until the arrival of the railroad and the new technology acquired following the Spanish-American war in 1848 brought irreversible changes.

\section{San Ygnacio}

Spanish Colonial-period structural sites, many with intact structures, are frequently found in the southern portion of the proposed project area, particularly within Zapata County. Many of these structures have been recorded (Hume 1972) by the Texas Historical Commission and have been listed on the National Register of Historic Places. A major section of San Ygnacio, a small community south of Laredo, has received status as a National Register Historic District.

The San Ygnacio Historic District encompasses most of the small south Texas community of San Ygnacio in Zapata County. It is bounded by the Rio Grande on the west, Highway 83 on the east, Mina Street on the north, and Matamoros Street on the south. Located approximately 35 miles south of Laredo, San Ygnacio was initially established in 1830 (Hume 1972). During that year, Don Jesus Trevino, who was reportedly from old Guerrero (also called Revilla, one of the 12 original Spanish colonies founded by Jose De Escandon in 1749 [(Hume 1972]), apparently purchased land from the Vasquez Borrego heirs ${ }^{1}$ (Warren

\footnotetext{
${ }^{1}$ Don Jose Vasquez Borrego and his wife Josepha Imperial were originally granted lands on the Texas side of the Rio Grande totalling about 350,000 acres. Don Joses's ranch headquarters, Rancho Dolores, was situated a few miles north of San Ygnacio.
} 
1989a C:10). With the construction of a small, stone residence, he established a ranching headquarters and construction on the Trevino headquarters continued until at least 1857 (Hume 1972). By 1874, a minimum of eight other structures had been added to the San Ygnacio settlement along the river.

In 1972, 36 buildings reflecting the vernacular expression typical of the Spanish Colonial period in south Texas were inventoried. Many of the homes in San Ygnacio were still active, and most of the early period structures examined then were (and probably are) still being used as residences. Hume (1972), who conducted this inventory for the Texas State Historical Survey Committee, concluded that:

[t]he San Ygnacio Historic District represents the last south Texas community with a large number of the once numerous sandstone structures constructed in the middle and late 19th century. The buildings here share a close stylistic and temporal relationship with many of the structures at Revilla (now partially inundated by Falcon Lake). San Ygnacio is an intact community which is the only community left in south Texas that expresses the total community through its 19th century development.

\section{Fort McIntosh}

Depredation by Lipan Apaches and Comanches had plagued the Laredo settlement since the 1730s. Prior to the Treaty of Guadalupe Hidalgo, a Spanish garrison was situated in Laredo to minimize Indian raiding. In 1790 a daring attack on the city overran the garrison and exploded the powder magazine, deepening fears "that the Comanches' efforts to sweep through south Texas were succeeding" (Briggs 1982:7). Once the Texas-Mexico border was established along the Rio Grande in 1848, the role of protection in the Laredo area was passed to the United States. In 1849, a company of mounted infantry under 2nd Lieutenant E. L. Viele arrived in Laredo to establish an army post on "some high flats west of the city, opposite a ford and just north of a bend in the Rio Grande" (Briggs 1982:7) on the Texas side of the river about three-quarters of a mile west of the old Spanish town of Laredo. Originally named Camp Crawford (and sometimes called Camp Laredo), in 1850 the name of the post was changed to Fort McIntosh, in honor of Lieutenant Colonel James S. McIntosh, who died September 1847 from wounds received at the Battle of Molino del Rey during the Mexican-American War (Frazer 1972). When construction began in 1850 , the general military objective of the Fort was to provide " . . escort service to caravans of travelers and [to reduce] Indian depredations and general outlawry . . . " (Briggs 1982:8).

Throughout Fort McIntosh's early period, enlisted men apparently camped in tents and under brush arbors at various locations in and around the cantonment area and outside the Field (Star) Fort. After a year without Indian depredations in the area, Fort McIntosh was abandoned. The following year (1860), however, the post was reoccupied due to raiding, only to be abandoned in 1861 as Texas took possession of it during the Civil War. At the close of the war in 1865, the infantry again arrived at Fort McIntosh. They found that much of the fort had been dismantled and removed during the war, leaving it essentially devoid of structures. By 1869, construction was again underway and a new post hospital, storehouse, guardhouse, and bakery were completed by 1870 . During the last major construction period in the 1880 s, buildings at the Fort were constructed of yellow Laredo brick; many of these structures remain today.

Until its final military abandonment in 1949, Fort McIntosh continued to be used for military training of troops and in 1942 became the home of the Southern Liaison Patrol of the newly formed Civil Air Patrol (Briggs 1982). According to Warren (1991:7), "[d]uring its long history, Fort McIntosh was involved in protecting local settlers and travelers from Indians and bandits, and played a role in the Civil War, the Mexican Revolution, the Spanish American War, and World Wars I and II. 
Since 1946, Fort McIntosh has been utilized as a teaching facility, housing Laredo Junior College. Although the post has been altered to meet the needs of a college campus, several structures and some of its early period subsurface deposits remain potentially intact (Briggs 1982:25, 26). Thus, Fort McIntosh, including Star Fort, maintains its National Register District status.

\section{Star Fort}

Star Fort, constructed in 1853 and included with Fort McIntosh on the National Register of Historic Places, lies near the proposed route. The property was flagged for avoidance during construction, and was later fenced for protection. The remains of this "early" or "Field Fort McIntosh" have been reported by several researchers including Briggs (1982) and Warren (1987, 1988, 1989a, 1989b, 1991). This earthen fortification appears today as a series of low mounds or embankments without visible associated cultural debris.

The 5th Infantry arrived at Fort McIntosh in November 1853 and, under direction of the Army Corps of Engineers, began construction of a Field Fort, north of the McIntosh Cantonment (Figure 6). This Field Fort was constructed of earthen embankments and designed as an artillery emplacement. Due to its five-pointed shape, the bermed structure became known as Star Fort, as well as Field Fort McIntosh, and was located about one-half mile north of the post proper (Warren 1991:6). Star Fort was completed in less than three months, including a stone magazine within the enclosure. By the time it was abandoned in 1859, the cantonment area (south of Star Fort) included offices, storehouses, kitchens, a blacksmith shop, a sutler's store, stables, a hospital, a carpenter's shop, officers' quarters, a parade ground, and possibly even a ranch house, which predated the Fort (Briggs 1982:11).

\section{Cultural Chronology in Southern Texas}

\section{Prehistoric}

The prehistory of South Texas (Black 1989:48-57; Suhm et al. 1954) can essentially be divided into three major periods: (1) Paleo-Indian (9200 - 6000 B.C.); (2) Archaic, which has been subdivided into: Early Archaic (ca. 6000 - 2500 B.C.), Middle Archaic (ca. 2500 - 400 B.C.), Late Archaic (ca. 400 B.C. - A.D. 800); and (3) Late Prehistoric (A.D. $800-1600$ ). These prehistoric periods are principally defined by the presence of particular diagnostic projectile points, but are meant to demarcate general socio-cultural patterns based on ecology, technology, and subsistence strategies.

\section{Paleo-Indian}

The evidence of Paleo-Indian occupations in South Texas usually consists of surface finds found most frequently in the Nueces-Guadalupe and Rio Grande plains. Only two stratified Paleo-Indian sites have been excavated in the region: Buckner Ranch (Sellards 1940) and Berger Bluff (Brown 1987). Both sites were found deeply buried in alluvial terraces. Diagnostic artifacts of the Paleo-Indian period include (in chronological order) Clovis (Meltzer 1986), Folsom (Largent et al. 1991), Golondrina, Scottsbluff, and Angostura points (Figure 7), as well as finely flaked end scrapers made on blades and bifacially worked Clear Fork tools (Black 1989:48-49). 


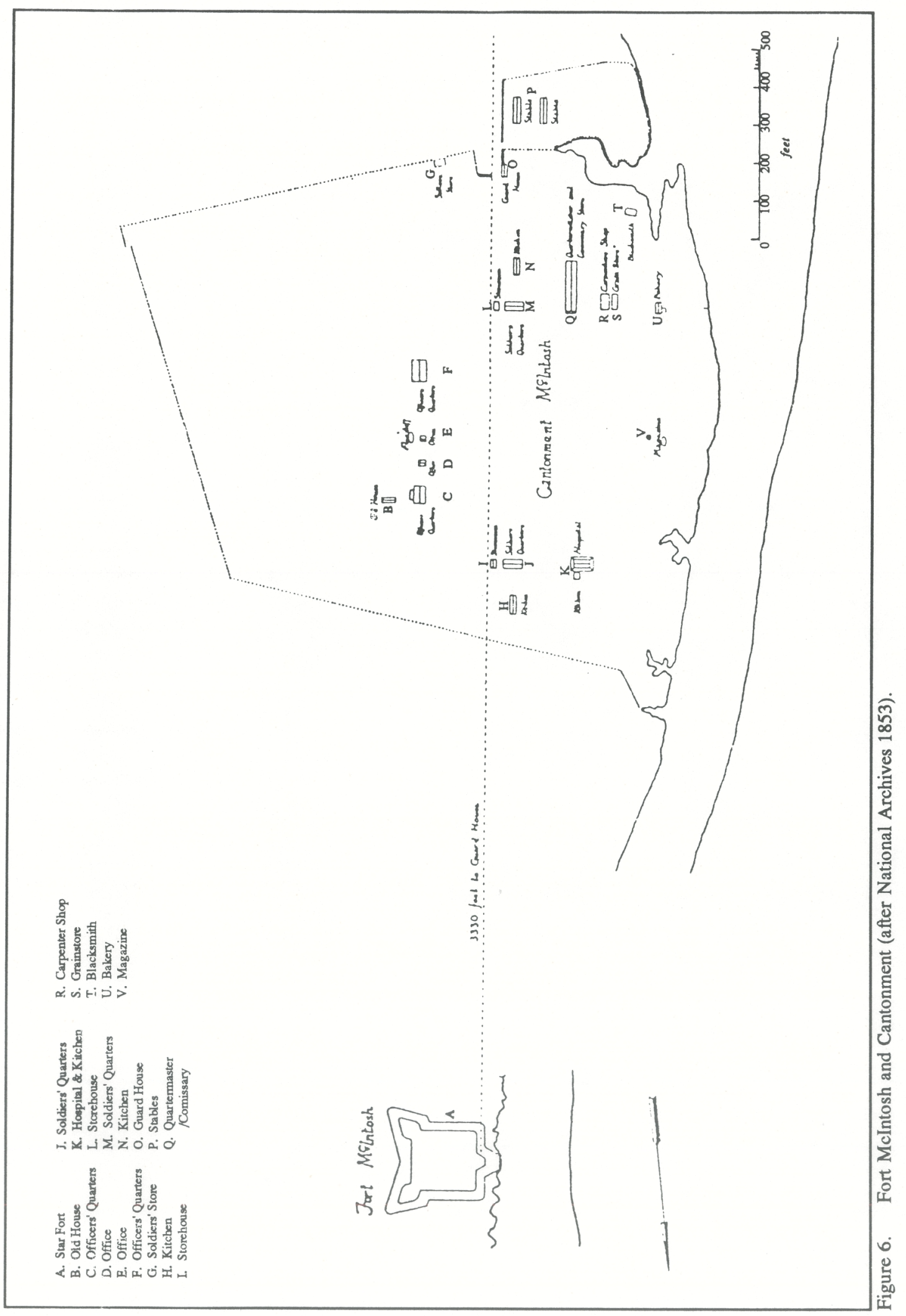




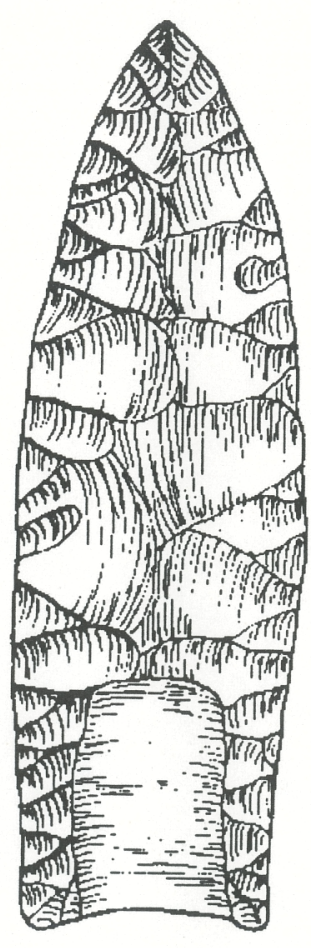

a

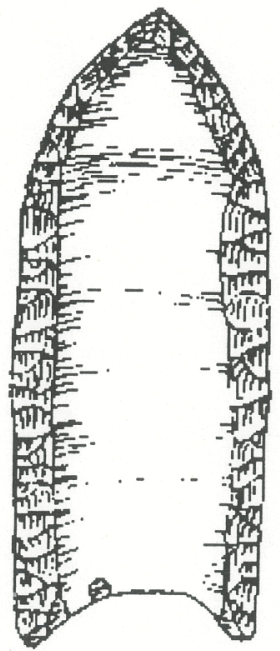

b

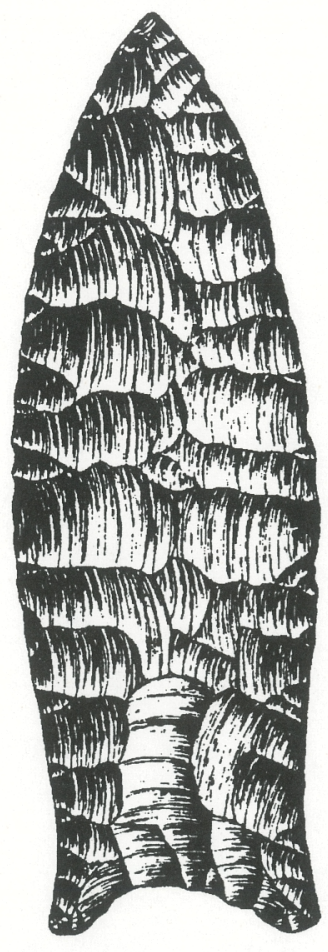

c

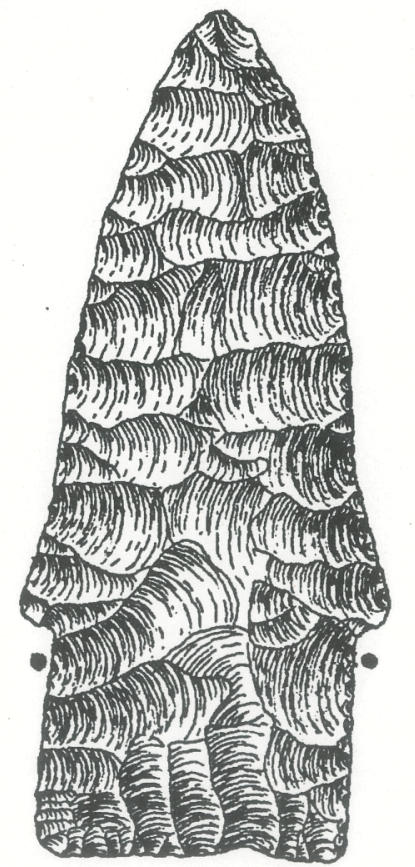

d

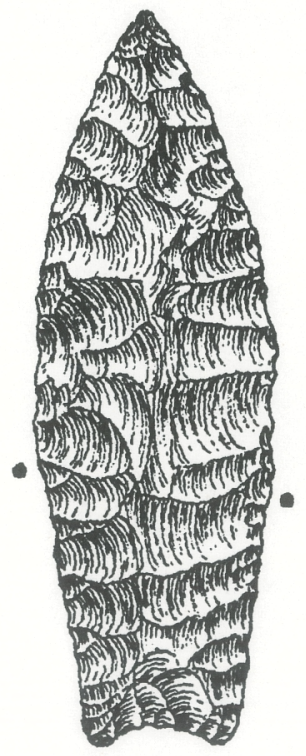

e

Figure 7. Diagnostic projectile points of the Paleo-Indian period of South Texas: (a) Clovis (Bell 1958); (b) Folsom (Bell 1958); (c) Golondrina (Perino 1971); (d) Scottsbluff (Turner and Hester 1985); and (e) Angostura (Turner and Hester 1985). (Scale 1:1) 
The various Paleo-Indian peoples are generally characterized as terminal Pleistocene big game hunters; however, this may reflect the greater archeological visibility of the "typical" kill sites. Contrary to the big game hunter model, investigations at Baker Cave indicate that a diverse array of fish, snakes, and rodents were exploited during this period (Hester 1983). Overall, Paleo-Indian populations were probably organized into small bands of less than 20 individuals who ranged over great distances across peri-glacial plains and marginally forested areas, to acquire different food sources throughout the year (Black 1989:48).

Archaic

The major distinction of the Early Archaic subperiod (6000-2500 B.C.) is the replacement of the earlier lanceolate-shaped projectile points with stemmed and corner-notched types. These styles include Bell, Andice, Early Triangular, and Early Expanding Stemmed points (Bandy, Martindale, Uvalde and related forms; Figure 8). Other diagnostic artifacts include large, thin, triangular bifaces with concave bases, and unifacially worked Clear Fork tools.

The beginning of the Early Archaic period also marks the onset of the modern Holocene era, in which the climatic setting shifted from a cooler, peri-glacial state (south of the glacial fields) to a warmer and more hospitable condition. Unlike other regions of Texas, there is no clear evidence in South Texas for an increase in population or restriction of territory during the Early Archaic period. Although this may reflect the relative dearth of data concerning this period, the available evidence in the Gulf Coastal Plain suggests that population densities were low, reflecting a continuation of the highly mobile, small band level of social organization (Black 1989:49).

The Middle Archaic (2500-400 B.C.) in South Texas is defined by the presence of Pedernales, Langtry, Kinney, Bulverde, and Tortugas projectile points (Figure 9). Medium to small, distally beveled tools are common in this period. Ground stone tools, including tubular grinding stones and manos, appear for the first time (Black 1989:49). During the Middle Archaic period, the number of sites in South Texas increased significantly, indicating a sustained growth in the population (Black 1989:51). Due to an increase in population, territoriality among Middle Archaic groups may have increased while mobility decreased, as is evidenced by the patterned occurrences of particular projectile points within certain areas of South Texas (Black 1989:51).

The Middle Archaic period may also reflect a shift to a heavier reliance on vegetal foods, as indicated by the archeological evidence in both Central and South Texas (Black 1989; Hall et al. 1982). The massive burned rock accumulations found at Choke Canyon, which appear to be related to the burned rock middens of Central Texas, were probably used to render acorns and mesquite beans into edible foods (Black 1989:49-51). On the coast there is also evidence that marine food sources (primarily shellfish) were being exploited as well during this time period.

Late Archaic (400 B.C.-A.D. 800) occupations in South Texas are defined by small corner- and sidenotched dart points including Ensor, Frio, Marcos, Fairland, and Ellis types (Figure 10). Based on the common occurrence of Late Archaic sites, population densities were higher during this period than in the preceding periods (Black 1989:51). The deeper deposits of cultural material appear to have been the result of more extended occupations or frequent reoccupations (Black 1989:51). Cemeteries also make their appearance, indicating higher levels of social organization and increased territoriality (Black 1989:51).

Overall, the Late Archaic period in South Texas represents an increase in the utilization of different ecological niches throughout the region and the intensification of activities geared towards the acquisition of seasonal food resources. This kind of adaptation is best illustrated by the frequent occurrence of shell middens along the coast and burned rock middens farther inland. Data collected from inland sites indicate 


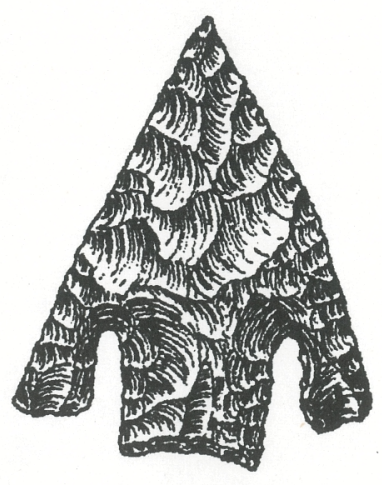

a

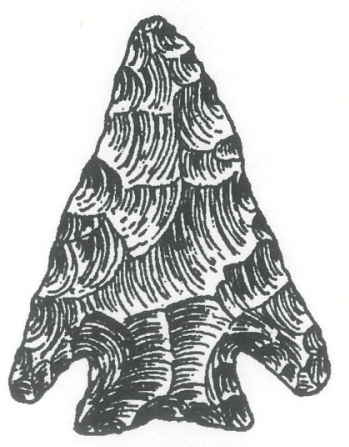

d

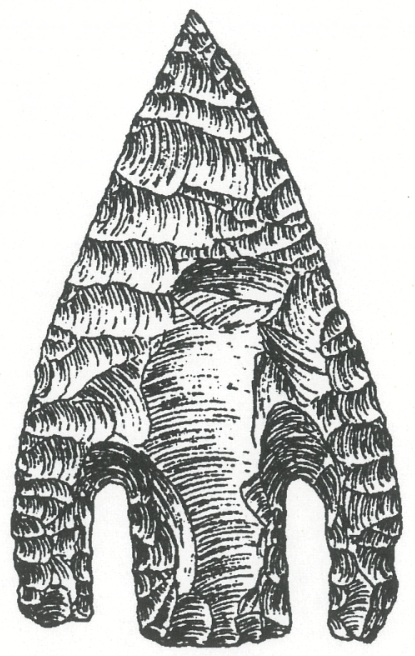

b

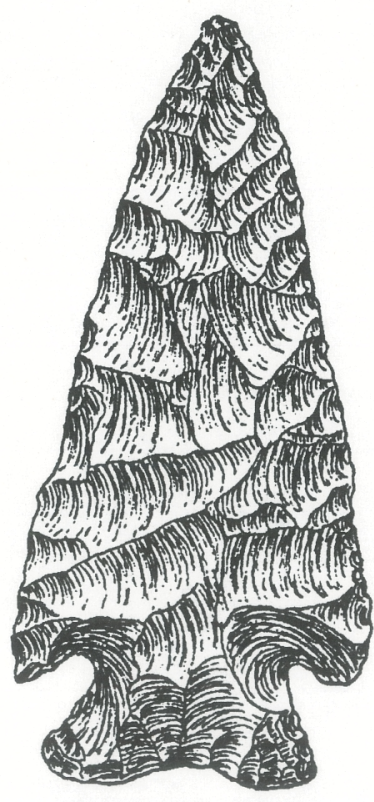

e

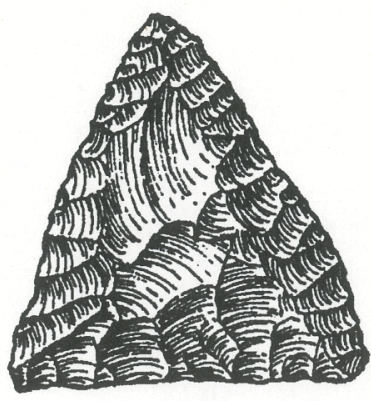

c

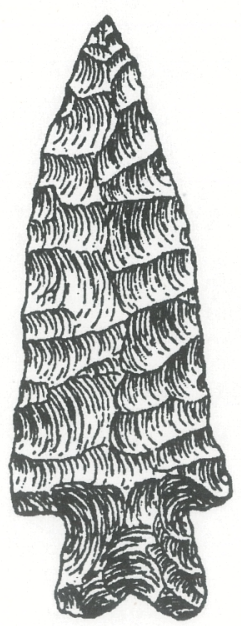

f

Figure 8. Diagnostic projectile points of the Early Archaic period of South Texas: (a) Bell; (b) Andice; (c) Early Triangular; (d) Bandy; (e) Martindale; and (f) Uvalde (Illustrations from Turner and Hester 1985).

(Scale 1:1) 


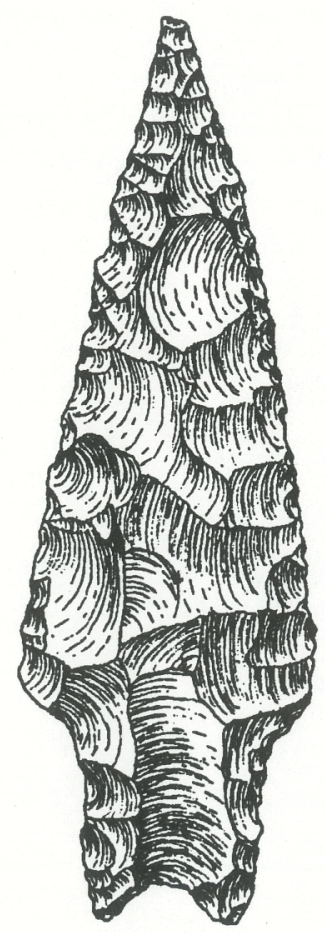

a

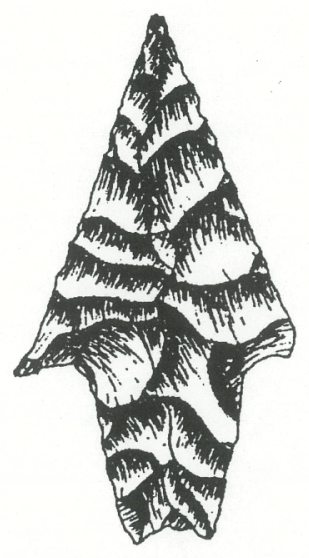

b

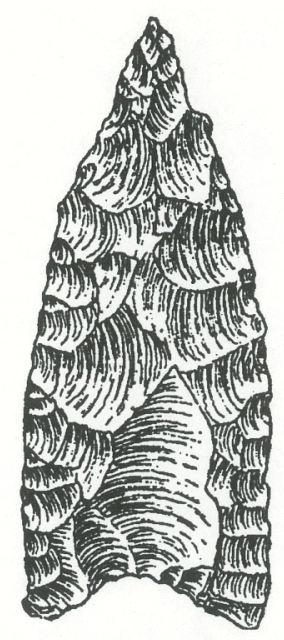

c

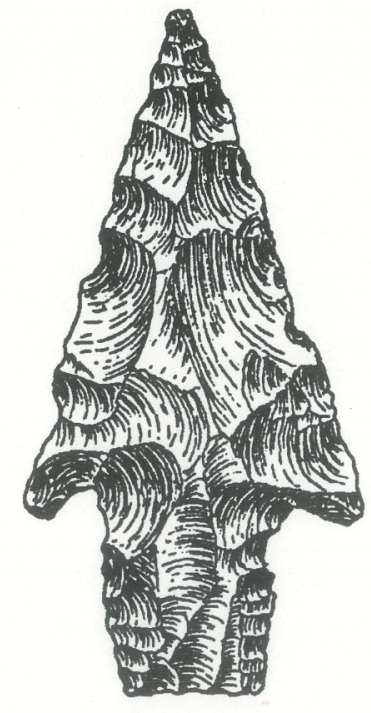

d

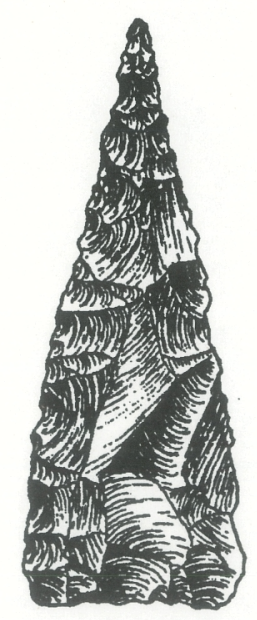

e

Figure 9. Dirgnostic projectile points of the Middle Archaic period of South Texas: (a) Pedernales (Turner and Hester 1985); (b) Langtry (Bell 1958); (c) Kinney (Turner and Hester 1985); (d) Bulverde (Turner and Hester 1985); and (e) Tortugas (Turner and Hester 1985). (Scale 1:1) 


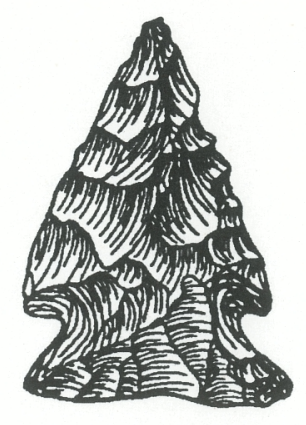

a

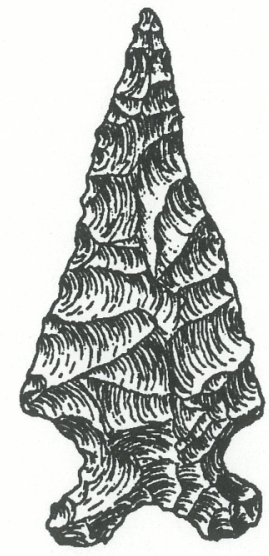

b

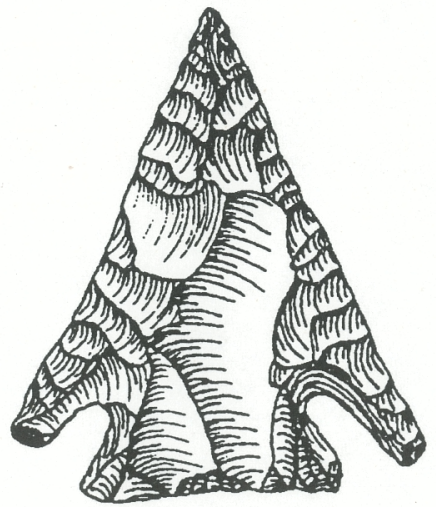

c

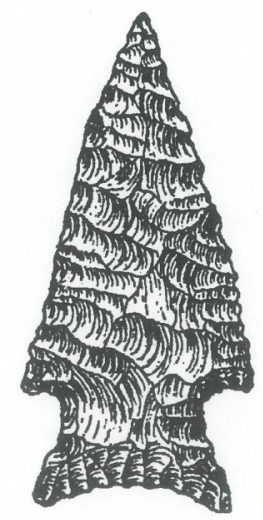

d

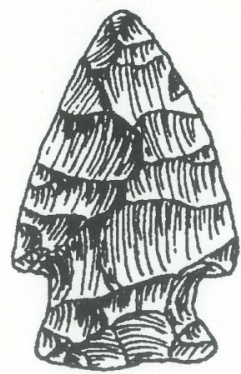

e

Figure 10. Diagnostic projectile points of the Late Archaic period of South Texas: (a) Ensor (Bell 1960); (b) Frio (Turner and Hester 1985); (c) Marcos (Bell 1958); (d) Fairland (Turner and Hester 1985); and (e) Ellis (Bell 1960). (Scale 1:1) 
that the economy was based primarily on vegetal resources supplemented with the hunting of small game such as rodents and rabbits (Black 1989:51).

\section{Late Prehistoric}

The Late Prehistoric period is defined by the appearance of pottery and the bow and arrow within the archeological record. The small dart points of the Late Archaic period were essentially replaced by arrow points (Black 1989:52). For most of South Texas, the Late Prehistoric period has been divided by Black (1986) into two sub-periods (phases); the Austin (A.D. 800-1350), and the Toyah (A.D. 1350-1600). The Austin phase is recognized by the presence of the Scallorn arrow point, while the Toyah phase is marked by the presence of Perdiz arrow points (Figure 11). These two phases are temporally equivalent to the similarly named phases in Central Texas and are believed to represent two successive population movements (or the diffusion of ideas) coming out of Central Texas into South Texas (Black 1986; 1989:52). Recent research by Ricklis (1992) indicated that, on the Texas Coast at least, it was the Late Prehistoric technology and not people that were spreading throughout South Texas at that time period.

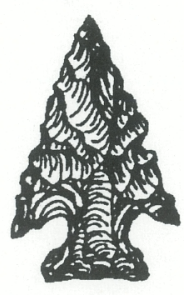

a

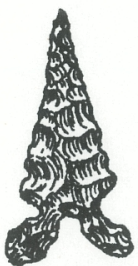

b

Figure 11. Diagnostic projectile points of the Late Prehistoric period of South Texas: (a) Scallorn; and (b) Toyah. (Scale 1:1)

Late Prehistoric sites are somewhat common throughout the region; this in turn is interpreted as the result of population increases. Faunal resources were increasingly important during this period, with a heavier reliance on large mammals such as bison and deer. The movement of bison from Central to South Texas probably coincides with the movement of peoples or technologies from both the Austin and Toyah phases (Black 1989:51-57). Lithic tool kits from these phases seem to have been manufactured for the processing of large mammals (Black 1989:51-57).

\section{Historic}

The historic era of South Texas began with the presence of Europeans in the region and can be subsumed within the general history of Texas. In South Texas, the historic era has been divided into three general time periods: (1) Spanish Exploration and Colonial (ca. 1520 - 1821), (2) Mexican (1821 - 1836), and (3) Texas-American (1836 - present). The Protohistoric era in this region can essentially be viewed as a subperiod of the early part of the Spanish Exploration and Colonial period. 


\section{Protohistoric}

Records from the initial Spanish expeditions have provided the earliest ethnohistoric accounts of the Coahuiltecan-affiliated groups indigenous to the Rio Grande Plain (Hester 1989a:1-4; 1989b:77-82). Based on fragmentary ethnohistorical records, it appears that these people -- part of a now-extinct cultural group who occupied lands stretching from South Texas deep into Mexico -- were hunter-gatherers who moved in a circulatory, seasonal pattern. Social organization was based on small bands with distinctive territories (which were sometimes shared with other groups). The lifestyle was highly nomadic; groups camped at preferred localities for only short periods. Given the documentary evidence, Coahuiltecans living in the Rio Grande Plain (as well as in other parts of South Texas and northern Mexico) subsisted on a number of seasonally based food resources, ranging from prickly pear in the fall to bison or deer in the late fall or winter, and small mammals and roots during the off-season or in times of hardship (Hester 1989b:7781).

The causes for the early destruction of the Coahuiltecan groups are two-fold. The primary reason stems from the great period of unrest among Native American groups generated by the introduction of the horse by the Spanish. Groups who adopted the horse (especially the Apache and the Comanche) eagerly took to raiding neighboring groups. Nomadic peoples such as the Coahuiltecans were especially vulnerable to such pressure, as they could neither consolidate for protection, nor occupy defensible positions without risking starvation. Finally, the Coahuiltecans asked for missions to be established in their territories in order to protect them from the Apache and Comanche raiders. After the establishment of the Spanish missions in South Texas during the first half of the eighteenth century, the remnants of the indigenous Native American groups were rapidly integrated into the mission system or were subjected to outright extinction by depredation or disease (John 1975:171-174).

\section{Spanish Colonial}

The first European incursion into Texas was by Alvarez de Piñeda in 1519. In 1528, Cabeza de Vaca crossed South Texas after having been shipwrecked along the Texas coast somewhere near Galveston Bay (Fox et al. 1989:85). Between 1688 and 1717, Spanish explorers such as Mazanet and Espinosa passed through the Rio Grande Plain from Mexico on their way to the Caddoan settlements in northeast Texas (Hester 1989b:80-81). Of course, these early Spanish explorers noted the aboriginal groups living in the region; however, they were primarily engaged in consolidating territory for the Spanish Crown.

After the founding of San Antonio in 1718, the town of Laredo was established along the Rio Grande in 1755 when rancher Tomas Sanchez de la Barrera y Gallardo was granted permission by the great Spanish colonizer, Jose de Escandon, to form a new settlement. Located in the province of Nuevo Santander, which included most of northeastern Mexico and parts of present-day Texas, Laredo was one of a series of settlements that Escandon established or authorized as part of Spain's effort to colonize the area south of the Nueces River (Clark and Juarez 1986:85; Folan et al. 1986:6).

Laredo was founded near a ford on the Rio Grande on a grant consisting of 15 sitios de ganado mayor, or 66,000 acres. In 1767, Spanish authorities visited the community and laid out San Agustin Plaza. They also granted porciones (parcels of land fronting on the river) to the settlers. The community grew steadily after its designation as a villa or town, and by 1789 , the population included approximately 700 individuals. There was a stone church and priest's house, military barracks to house the soldiers who guarded the population against frequent Indian attacks, and approximately 85 civilian dwellings, most of which were concentrated in the vicinity of San Agustin square. The economy centered around ranching and salt mining at Sal del Rey in present-day Hidalgo County (Anonymous n.d.:n.p.; Clark and Juarez 1986:87-88; Folan et al. 1986:6). 


\section{Mexican-Texas-American}

During the late eighteenth century and first half of the nineteenth century, the citizens of Laredo considered themselves to be separate from the Anglo-American settlements developing in other parts of Texas. Nevertheless, their key location on the corridor between Mexico and the United States involved them in Mexico's war for independence against Spain prior to 1821, in the events of the Texas revolution during the 1830s, and in the Mexican-American War of 1846-1848. Insurgents, troops, and supplies passed through the town with regularity, keeping the community in a constant state of flux for 50 years. Population turnover was continuous, although the number of residents changed little (Clark and Juarez 1986:89-95; Folan et al. 1986:6-7).

The organization of Webb County in 1848 and the increasing numbers of Anglo-American merchants afterwards contributed to a period of prosperity for Laredo. The town's economy was further stimulated during the Civil War, when it became a center for the Confederate cotton trade. Twenty years later, the arrival of the Texas-Mexican Railway and the International-Great Northern Railroad (1881) caused Laredo's population to soar, and within a decade the number of residents had increased from 3,521 to 11,319 (Anonymous n.d.:n.p.; Folan et al. 1986:8). A major influx of Anglo-American entrepreneurs resulted in the construction of an electric railway system, the stimulation of growth in the project area, opening of new suburban developments such as the Heights east of Zacate Creek, and construction of numerous residential and commercial buildings. The opening of coal mines northwest of Laredo also contributed to the general prosperity (Anonymous n.d.:n.p.), as did a period of intense agricultural development after 1900. Further significant population growth occurred during the second decade of the twentieth century as large numbers of Mexican nationals crossed the border to escape the ravages of civil war. Arriving in numbers that increased the population by 50 percent between 1910 and 1920 (Anonymous n.d.:n.p.), the new immigrants created a demand for housing throughout the city while contributing to the local infrastructure as teachers, businessmen, and laborers.

Discovery of oil in Webb County in 1921 assisted Laredo in sustaining a period of growth during the 1920s and 1930s, after which the city suffered the effects of the Great Depression. Establishment of the Laredo Army Air Field in 1942 aided in a general economic recovery that continued after World War II as the community became the location of numerous service industries. Increasing trade between the United States and Mexico further stimulated the local economy, which has remained strong throughout the last few decades. 



\section{METHODOLOGY}

\section{SURVEY}

Prior to the beginning of the fieldwork, the records of the Texas Archeological Research Laboratory (TARL) at the University of Texas at Austin were consulted to determine whether known sites exist within the impact areas. The cultural resources survey was conducted by personnel from Geo-Marine, Inc. Survey methods varied depending on the proposed impact. Along the 150 miles of road improvements, a reconnaissance level survey was conducted to determine whether any hearths, artifact concentrations, or other features were present within the impact areas. Along every road and railroad easement investigated, sufficient blading had occurred to obliterate any site context within the rights-of-way, although small quantities of artifacts were occasionally observed. No diagnostic artifacts were noted or examined in the field and no collection of artifacts was made.

The two firing ranges were subjected to intensive pedestrian survey with 15 meter transect intervals, with only a few non-diagnostic lithic artifacts being observed at the Freer Range. Both areas had been previously disturbed by the construction of roads and backstop berms, which allowed the inspection of subsurface stratigraphy and potential cultural deposits. The Laredo firing range was surveyed by the cultural resources monitor assigned to the proposed project.

Along the river front route, reconnaissance level survey was conducted only along the upper terrace, where previous investigations on this land form (McGraw 1983) had already located prehistoric sites. A segment of lower terrace was considered to be too geologically active for a pedestrian survey, as any cultural deposits would have been either removed by erosion or deeply buried. Star Fort, located on the northeastern edge of Laredo Junior College, was the only cultural property located along the Rio Grande road.

\section{MONITORING}

Upon arrival at the project site, the environmental monitor met with the U.S. Border Patrol (USBP) and Army Reserve officers in charge of the project. The USBP and Army Reserve were informed of the environmental monitor's purpose for being on site and of the environmental resources concerns in the project area.

The Army performed simultaneous construction activities at several widely separated locations during the operation. In addition, the Army requested that a few new areas be surveyed for environmental resources (Figure 12). For this reason, the environmental monitor was not able to be at each construction location continuously while construction activities were occurring. The environmental monitor met with the Army Reserve each morning and determined a priority list for the areas that needed to be monitored or surveyed during the day. The monitor was always in the environmentally sensitive areas during construction 


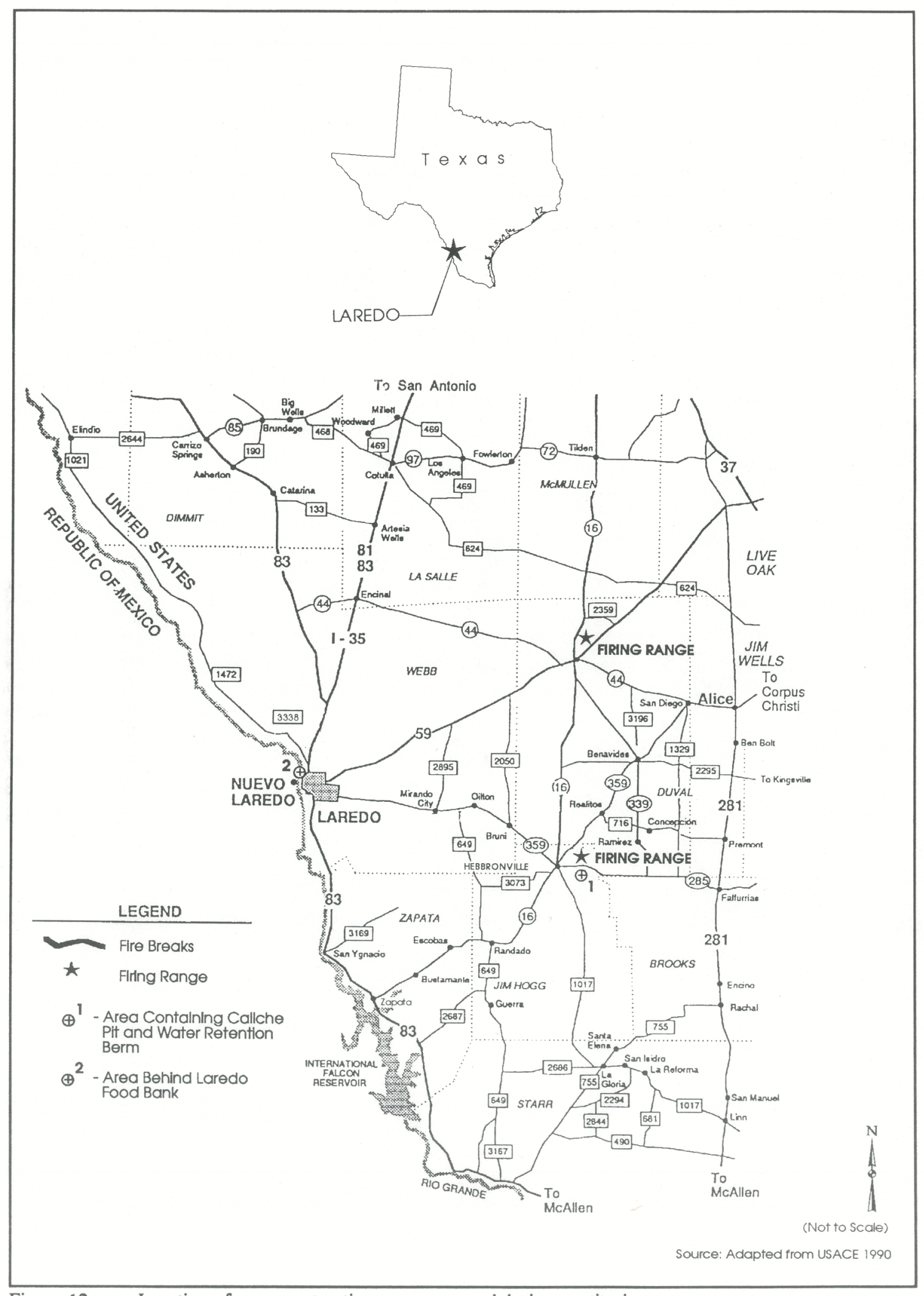

Figure 12. Location of new construction areas surveyed during monitoring. 
activities, unless two or more of these areas had activity occurring simultaneously. The sensitive Star Fort area was either monitored or inspected every day.

The monitor surveyed areas in front or along the side of the equipment as the construction unit progressed along its route. In areas with known biological and/or cultural resource sites, the monitor was stationed within and along the site until construction activities ceased in the area. 


\section{RESULTS}

\section{SURVEY}

As noted previously, extensive disturbance was noted within the impact areas of the 150 miles of proposed road and at the two firing ranges. Consequently, no cultural resource sites were located in these areas, although three lithic artifacts -- forming a non-site locality -- were observed on the Zapata Combat Trail. Along the Rio Grande, the survey identified the remains of Star Fort. This site was photographed, a site form was completed and the site perimeter was flagged for avoidance.

\section{MONITORING}

Environmental and cultural resources monitoring of the project area continued for the six weeks during which upgrade and construction activities were performed. These results are detailed below; as this is a cultural resources report only, references to environmental and biological resources were not included in this account.

\section{Week 1: July 10-17, 1993}

The environmental monitor met with USBP Agent W. King, U.S. Army Reserve Captain G. Santiago, and Colonel W. Wedge on July 11, 1993. Various project concerns were discussed and the areas of environmental concern were emphasized during the meeting. Site visits to the River Road, Zapata Combat Trail, and Laredo Firing Range were made after the meeting. An orientation meeting was held, and the troops were notified about sensitive environmental areas in the project region. The Star Fort area was encircled with engineering tape by U.S. Army Reserve surveyors. Mr. Louis Webber with the Webb County Historical Commission also visited the area around Star Fort.

During the course of this week, the environmental monitor observed construction activities along the River Road, at the Freer Firing Range, the LJC complex, Highway 83 north, and at the Hebbronville Firing Range. No new cultural resources were identified, and existing cultural resources were not affected by construction activities during the week.

Week 2: July 18-24, 1993

The environmental monitor continued to observe construction activities along the River Road; at the Laredo, Freer, and Hebbronville firing ranges; and at the LJC complex areas. A section of engineering tape surrounding Star Fort was torn down in the vicinity of a dirt road through the area. Agent King and 
Captain Smith were notified and the tape was replaced. New cultural resource sites were not located during the week.

Week 3: July 25-31, 1993

The second rotation of U.S. Army Reserve personnel arrived. An orientation meeting was held with the new troops and project leaders. Avoidance of the sensitive biological and cultural resource areas was emphasized during the meeting. The environmental monitor observed construction activities along the River Road, along the Cotulla Drag Road, at the Freer Firing Range, at the LJC complex, along Highway 83 north, and along Interstate 35 . No new cultural resources were observed and existing cultural resources were not affected by construction activities during the week.

Week 4: August 1-7, 1993

On Sunday, August 1, 1993, Agent King and Captain Santiago requested permission to perform several additional projects. The list of additional projects was sent to Mr. Eric Verwers at the USACOE/Fort Worth District for review and approval.

The environmental monitor observed construction activities along the River Road, at the Freer and Hebbronville firing ranges, and along the Zapata Combat Trail. While observing construction on the Zapata Combat Trail, the environmental monitor located one broken projectile point and two flakes in the highway right-of-way 1.1 miles north of San Ygnacio. No other cultural features or artifacts were found in the area. As a result, this find has been classified as a non-site locality and is considered ineligible for inclusion in the National Register of Historic Places.

At the request of Agent King, a two-acre area behind the Laredo Food Bank and adjacent to the River Road was surveyed for threatened and endangered species and cultural resources. Neither endangered/threatened species nor cultural resources were found at these locations during the survey. No endangered/threatened species or cultural resources were affected by construction activities during the week.

\section{Week 5: August 8-14, 1993}

The third rotation of Army Reserve personnel arrived in Laredo. The monitor visited the Hebbronville, Freer, and Zapata project areas with Agent King, Captain Santiago, and the new project leaders. An orientation meeting was held with the new troops.

The environmental monitor observed road repair work along the Zapata Combat Trail, Tiendes Drag Road, the Hebbronville Firing Range, and along the Hebbronville Drag Road. The Zapata Combat Trail was completed without impacts to the cultural resources in the area.

On August 11, 1993, the monitor was requested by the USACOE to survey an additional construction area for cultural resources. The new area, near the Hebbronville Firing Range, contained a series of berms intended to hold municipal wastewater treatment plant effluent and to create wetlands. One berm was eroded and in need of repair. The majority of repair work to the berm was completed before the monitor was able to survey the area, due to an apparent miscommunication between the monitor and U.S. Army Reserve personnel. When the monitor arrived on site, a 20'x 50'x 1' area had already been disturbed by construction equipment. The construction was stopped and the monitor surveyed the area. Cultural resources were not found during the survey of the project area. 
On August 13, 1993, the environmental monitor met with U.S. Army Reserve surveyors and Mr. Louis Webber to mark the position where a chain link fence would be installed around Star Fort. The area for the new fence line was marked at 40 meters from the south side of the Fort.

No cultural resources were affected by construction activities during the week.

Week 6: August 15-19, 1993

The environmental monitor observed the work progress on the Freer Combat Trail and inspected the completed Hebbronville Drag Road. A final inspection of the completed Freer Firing Range and Freer Combat Trail was made later during the week.

At 2100 hours on August 15, 1993, the monitor was notified by the USBP that a grader had gone through the engineering tape surrounding Star Fort and had lightly graded an existing road through the Fort. Work was immediately halted in the area around Star Fort on the morning of August 16, 1993, and an investigation of the incident was initiated. The environmental monitor, Captain Santiago, and Agent King surveyed the area affected by the incident. No artifacts appeared to have been unearthed and no apparent damage to the Fort itself had occurred. The USACOE/Fort Worth District was notified of the incident. Later in the morning on August 16 the order to restart work was received from the USACOE/Fort Worth District. Under guidance of the monitor, a grader cleared a narrow path through a mesquite thicket to allow for installation of the fence around Star Fort. On August 18 the fence around the Star Fort area was completed. 


\section{SUMMARY AND RECOMMENDATIONS}

Impacts to historic properties within the Laredo region were avoided through limitation of the improvements to previously disturbed contexts and avoidance of properties listed in and eligible for inclusion on the National Register of Historic Places. The actions along the firebreak sections were limited to road maintenance and removal of grass cover within existing road and railroad rights-of-way; therefore, no additional impact on previously recorded cultural properties could be expected, and none was observed. The location of the proposed fitness/obstacle course is on an old industrial area and has been previously determined to not contain significant cultural resources. The areas to be repaired at the firing ranges are currently used for that purpose and, therefore, cultural resources will not be affected.

Avoidance of areas directly adjacent to Star Fort and the town of San Ygnacio, both National Register properties, resulted in no significant impacts to these properties. The area of Star Fort was flagged so that construction crews would avoid the area, and a cultural resources monitor was assigned to the construction projects to ensure avoidance of all cultural and historic properties within and adjacent to the project area. However, due to a miscommunication, Star Fort was intruded upon during road-grading activities. Fortunately, no archeological deposits were impacted. Star Fort was fenced by the JTF- 6 crews subsequent to the disturbance, as was originally planned.

Based on the findings of this cultural resources investigation of each of the actions, in addition to the results of six weeks of environmental monitoring, no significant impacts to the cultural resources of the region occurred during the JTF- 6 construction projects. In addition, no new cultural resources sites were identified within the impacted areas. It is therefore the recommendation of this report that any future actions in these areas can be implemented with no further consideration of the cultural resources of the region, other than the presence of an environmental monitor at the worksites. 



\section{REFERENCES CITED}

Anderson, A.E.

1932 Artifacts of the Rio Grande Delta Region. Bulletin of the Texas Archaeological and Paleontological Society 4:29-31.

Anonymous

n.d. Laredo History, from First Settlements to 1899. Part 1. Typescript in the collections of Laredo Public Library, Laredo, Texas.

Bell, R.E.

1958 Guide to the Identification of Certain American Indian Projectile Points. Special Bulletin No. 1. Oklahoma Anthropological Society, Norman.

1960 Guide to the Identification of Certain American Indian Projectile Points. Special Bulletin No. 2. Oklahoma Anthropological Society, Norman.

Black, S.L.

1986 The Clemente and Herminia Hinojosa Site, 41JW8: A Toyah Horizon Campsite in Southern Texas. Special Report 18. Center for Archaeological Research, The University of Texas at San Antonio.

1989 South Texas Plain. In From the Gulf to the Rio Grande: Human Adaptation in Central, South, and Lower Pecos Texas, edited by T.R. Hester, S.L. Black, D.G. Steele, B.W. Olive, A.A. Fox, K.J. Reinhard, and L.C. Bement, pp. 39-62. Arkansas Archeological Survey Research Series No. 33, Fayetteville.

Blair, W.F.

1950 The Biotic Provinces of Texas. Texas Journal of Science 2:93-117

Briggs, A.K.

1982 Archaeological Investigations of an Area Proposed for Vegetation Management at Fort McIntosh, USA (1849-1946), Laredo, Webb County, Texas. Report \#19, Lone Star Archaeological Services, Georgetown, Texas.

Brown, D.O.

1983 The Berger Bluff Site (41GD30A): Excavations in the Upper Deposits. Archaeological Survey Report 115. Center for Archaeological Research, The University of Texas at San Antonio. 
Brown, K.M.

1987 Early Occupations at Berger Bluff, Goliad County, Texas. Current Research in the Pleistocene 4:3-5.

Campbell, T.N.

1947 The Johnson Site: Type Site of the Aransas Focus of the Texas Coast. Bulletin of the Texas Archaeological and Paleontological Society 18:40-75.

1952 The Kent-Crane Site: A Shell Midden on the Texas Coast. Bulletin of the Texas Archaeological and Paleontological Society 23:36-77.

1956 Archeological Materials from Five Islands in the Laguna Madre, Texas Coast. Bulletin of the Texas Archeological Society 27:7-46.

1958 Archeological Remains from the Live Oak Point Site, Aransas County, Texas. The Texas Journal of Science 10:432-442.

1962 Origin of Pottery Types from the Coastal Bend Region of Texas. Bulletin of the Texas Archeological Society 32:331-336.

Campbell, T.N., and J.Q. Frizzell

1949 Notes on the Ayala Site, Lower Rio Grande Valley, Texas. Bulletin of the Texas Archaeological and Paleontological Society 20:63-72.

Carlson, D.L., D.G. Steele, and H.L. Bruno

1982 Archeological Investigations at the Allison Site (41NU185), Nueces County, Texas. Reports of Investigations 1. Archeological Research Laboratory, Texas A\&M University, College Station.

Cason, J.F.

1952 Report on Archaeological Salvage in Falcon Reservoir, Season of 1952. Bulletin of the Texas Archeological Society 23:218-259.

Clark, J.W., Jr. and A.M. Juarez

1986 Urban Archeology: A Cultural History of a Mexican-American Barrio in Laredo, Webb County, Texas. Volume I: Background, Methods, Lot Descriptions, Features, Neighborhood Historical Overview. Report No. 31., Publications in Archeology. Texas State Department of Highways and Public Transportation, Highway Design Division. Austin.

Corbin, J.E.

1963 Archeological Materials from the Southern Shore of Corpus Christi Bay, Texas. Bulletin of the Texas Archeological Society 34:5-30.

Fitzpatrick, W.S., J. Fitzpatrick, and T.N. Campbell

1964 A Rockport Black-on-Gray Vessel from the Vicinity of Corpus Christi, Texas. Bulletin of the Texas Archeological Society 35:193-204.

Folan, W.J., P. Cox, A.A. Fox, and G.M. Hinojosa

1986 Laredo, Texas: Gateway Community on the Texas Borderlands, Archeological and Historical Investigations for the Laredo City Toll Plaza. Archaeological Survey Report No. 116. Center for Archaeological Research, The University of Texas at San Antonio. 
Fox, A.A.

1979 Archaeological and Historical Investigations at 41BX180, Walker Ranch, San Antonio, Texas: Phase 1. Archaeological Survey Report 83. Center for Archaeological Research, The University of Texas at San Antonio.

Fox, A.A. and T.R. Hester

1976 An Archaeological Survey of Coleto Creek, Victoria and Goliad Counties, Texas. Archaeology Survey Report 18. Center for Archaeological Research, The University of Texas at San Antonio.

Fox, A.A., S.L. Black, and S. James

1979 Intensive Survey and Testing of Archaeological Sites on Coleto Creek, Victoria and Goliad Counties, Texas. Archaeological Survey Report 67. Center for Archaeological Research, The University of Texas at San Antonio.

1989 Historic Anglo-European Exploration and Colonization. In From the Gulf to the Rio Grande: Human Adaptation in Central, South, and Lower Pecos Texas, edited by T.R. Hester, S.L. Black, D.G. Steele, B.W. Olive, A.A. Fox, K.J. Reinhard, and L.C. Bement, pp. 85-92. Research Series No. 33, Arkansas Archeological Survey. Fayetteville.

Fox, D.E.

1974 Archaeological Resources of the Proposed Cuero I Reservoir, DeWitt and Gonzales Counties, Texas. Archaeological Survey Report 12. Texas Historical Commission and Texas Water Development Board. Austin.

Fox, D.E., and H.G. Vecker

1977 The Archaeological Study of the McPherson Road Extension Project, Laredo, Texas. Archaeological Survey Report \#45, University of Texas at San Antonio.

Frazer, R.W.

1972 Forts of the West: Military Forts and Presidios and Posts Commonly Called Forts West of the Mississippi River to 1898. University of Oklahoma Press, Norman.

Hall, G.D., S.L. Black, and C. Graves

1982 Archeological Investigations at Choke Canyon Reservoir, South Texas: The Phase I Findings. Choke Canyon Series 5. Center for Archaeological Research, The University of Texas at San Antonio.

Hartle, D.D., and R. L. Stephenson

1951 Archaeological Excavations at the Falcon Reservoir, Starr County, Texas. River Basins Survey, Smithsonian Institution. Unpublished manuscript on file at the Center for Archaeological Research, The University of Texas at San Antonio.

Hester, T.R.

1968a Paleo-Indian Artifacts from Sites along San Miguel Creek: Frio, Atascosa, and McMullen Counties, Texas. Bulletin of the Texas Archeological Society 39:147-161.

1968b Notes on Some Pottery-bearing Sites in Southern Texas. The Bull-Roarer 3(2):9-11. The University of Texas Anthropological Society, Austin.

1968c Folsom Points from Southwest Texas. Plains Anthropologist 13(40):117. 
1969 Archeological Investigations in Kleburg and Kenedy Counties, Texas. Archaeological Program, Report 13. State Building Commission.

1980 Digging into South Texas Prehistory. Corona Publishing, San Antonio.

1983 Late Paleo-Indian Occupations at Baker Cave, Southwestern Texas. Bulletin of the Texas Archeological Society 53:101-119.

1989a Introduction. In From the Gulf to the Rio Grande: Human Adaptation in Central, South, and Lower Pecos Texas, edited by T.R. Hester, S.L. Black, D.G. Steele, B.W. Olive, A.A. Fox, K.J. Reinhard, and L.C. Bement, pp. 1-4. Research Series No. 33, Arkansas Archeological Survey. Fayetteville.

1989b Historic Native American Populations. In From the Gulf to the Rio Grande: Human Adaptation in Central, South, and Lower Pecos Texas, edited by T.R. Hester, S.L. Black, D.G. Steele, B.W. Olive, A.A. Fox, K.J. Reinhard, and L.C. Bement, pp. 79-84. Research Survey Series No. 33, Arkansas Archeological Survey. Fayetteville.

Hester, T.R., M.B. Collins, F.A. Weir, and F. Ruecking, Jr.

1969 Two Prehistoric Cemetery Sites in the Lower Rio Grande Valley of Texas. Bulletin of the Texas Archeological Society 40:119-166.

Hester, T.R., and T.C. Hill, Jr.

1969 Mogollon Artifacts from Southern Texas. The Artifact 7(3):11-15.

Hester, T.R., S.L. Black, D.G. Steele, B.W. Olive, A.A. Fox, K.J. Reinhard, and L.C. Bement

1989 From the Gulf to the Rio Grande: Human Adaptation in Central, South, and Lower Pecos Texas. Research Series No. 33, Arkansas Archeological Survey. Fayetteville.

Highley, C.L.

1986 Archaeological Investigations at 41CK201, Choke Canyon Reservoir, Southern Texas. Choke Canyon Series 11. Center for Archaeological Research, The University of Texas at San Antonio.

Hume, G.L.

1972 San Ygnacio Historic District 41ZP97. National Register of Historic Places Inventory Nomination Form. Texas State Historical Survey Committee, Austin, Texas.

Jackson, A.T.

1940 Tubular Pipes and Other Tubes in Texas. Bulletin of the Texas Archaeological and Paleontological Society 12:99-137.

Jelks, E.B.

1952 The River Basin Surveys Archeological Salvage Program in Texas. Texas Journal of Science 4(2):131-138.

1953 The River Basin Surveys: Recent Archeological Investigations in Texas, Arkansas and Kansas. Texas Journal of Science 5(3):341-347. 
John, E.A.H.

1975 Storms Brewed in Other Men's Worlds: The Confrontation of Indians, Spanish, and French in the Southwest, 1540-1795. University of Nebraska Press. Lincoln and London.

Kreiger, A.D.

n.d. Archeology, Ethnography, and Early Spanish History of Falcon Reservoir Area. Unpublished manuscript on file, Texas Archeological Research Laboratory, The University of Texas at Austin.

Kreiger, A.D., and J.T. Hughes

1950 Archaeological Salvage in the Falcon Reservoir Area: Progress Report 1. Mimeographed. On file, Texas Archeological Research Laboratory, The University of Texas at Austin.

Largent, F.B., Jr., M.R. Waters, and D.L. Carlson

1991 The Spatiotemporal Distribution of Folsom Projectile Points in Texas. Plains Anthropologist 36(137):323-341.

Lynn, J.M., D.E. Fox, and N. O'Malley

1977 Cultural Resource Survey of Choke Canyon Reservoir, Live Oak and McMullen Counties, Texas. Archeological Survey Report 20. Office of the State Archeologist, Texas Historical Commission, Austin.

McGraw, J.A.

1983 Arroyo de los Muertos and other Prehistoric Terrace Sites Along the Rio Grande, Laredo, Texas. Archaeological Survey \#106, University of Texas at San Antonio.

MacNeish, R.S.

1947 A Preliminary Report on Coastal Tamaulipas. American Anthropologist 13:1-15.

1958 Preliminary Archeological Investigations in Sierra de Tamaulipas, Mexico. Transactions of the American Philosophical Society 48:6.

Mallouf, R.J., B.J. Baskin, and K.L. Killen

1977 A Predictive Assessment of Cultural Resources in Hidalgo and Willacy Counties, Texas. Survey Report 25. Office of the State Archeologist, Texas Historical Commission. Austin.

Martin, G.C.

1929 Notes on Some Texas Coast Campsites and Other Remains. Bulletin of the Texas Archaeological and Paleontological Society 1:50-57.

1930a Two Sites on Callo Del Oso, Nueces County, Texas. Bulletin of the Texas Archaeological and Paleontological Society 2:7-17.

1930b A Vase and Some Carved Stones and Pebbles from Nueces County, Texas. Bulletin of the Texas Archaeological and Paleontological Society 2:18-30.

1931 Texas Coastal Pottery. Bulletin of the Texas Archaeological and Paleontological Society 3:5356. 
Martin, G.C., and W.H. Potter

n.d. Preliminary Archaeological Survey of a Portion of the Texas Coast. Privately printed, ca. 1931. On file, Texas Archeological Research Laboratory, The University of Texas at Austin.

Meltzer, D. J.

1986 The Clovis Paleoindian Occupation of Texas: Results of the Texas Clovis Fluted Point Survey. Bulletin of the Texas Archeological Society 57:27-86.

Nunley, P., and T.R. Hester

1966 Preliminary Archeological Investigations in Dimmit County, Texas. Texas Journal of Science 18(3):233-253.

Patterson, J.T.

1936 The Corner-Tang Flint Artifacts of Texas. Bulletin 3618, Anthropological Papers 1(4). The University of Texas, Austin.

Perino, G.

1971 Guide to the Identification of Certain American Indian Projectile Points. Special Bulletin No. 3. Oklahoma Anthropological Society, Norman.

Poteet, S.

1938 The Occurrence and Distribution of Beveled Knives. Bulletin of the Texas Archaeological and Paleontological Society 10:245-262.

Potter, W.H.

1930 Ornamentation on the Pottery of the Texas Coastal Tribes. Bulletin of the Texas Archaeological and Paleontological Society 2:41-44.

Rand McNally

1993 Road Atlas. 69th Edition pp. 128. Rand McNally, Chicago, Illinois.

Ricklis, R.A.

1992 The Spread of a Late Prehistoric Hunting Complex: Evidence from the South-Central Coastal Prairie of Texas. Plains Anthropologist 37(140):261-274.

Sayles, E.B.

1935 An Archaeological Survey of Texas. Medallion Papers XVII. Gila Pueblo, Globe, Arizona.

Sanders, R.R., and W.J. Gabriel

1985 Soil Survey of Webb County, Texas. Soil Conservation Service, United States Department of Agriculture.

Sellards, E.H.

1940 Pleistocene Artifacts and Associated Fossils from Bee County, Texas. Bulletin of the Geological Survey of America 51:1627-1657.

Shafer, H.J., and C.L. Bond

1985 An Archeological Review of the Central Texas Coast. Bulletin of the Texas Archeological Society 54:271-286. 
Sobolik, K.D.

1991 Prehistoric Diet from the Lower Pecos Region of Texas. Plains Anthropologist 36(135):139152.

Story, D.A.

1968 Archeological Investigations at Two Central Texas Gulf Coast Sites. Report 13. Archeological Program, State Building Commission. Austin.

Suhm, D.A., A.D. Kreiger, and E.B. Jelks

1954 An Introductory Handbook of Texas Archeology. Bulletin of the Texas Archeological Society 25 .

Turner, E.S. and T.R. Hester

1985 A Field Guide to Stone Artifacts of Texas Indians. Texas Monthly Press, Austin.

U.S. Army Corps of Engineers

1990 Environmental Assessment of Joint Task Force Six Operation 3-90, Webb, LaSalle, Jim Hogg, and Duval Counties, Texas. U.S. Army Corps of Engineers, Fort Worth District, Texas.

1993 Scope of Work for Environmental Assessment, Laredo, Texas, JTF-6 Road Repair and Firing Range Repair Project. U.S. Army Corps of Engineers, Fort Worth District, Fort Worth, Texas.

Usrey, S.

1980 Archeological Investigations at Seven Sites in Atascosa County, Texas. Report 48. Anthropology Laboratory, Texas A\&M University, College Station.

Wakefield, W.

1968 Archeological Survey of Palmetto Bend and Choke Canyon Reservoir, Texas. Survey Report 5. Texas Archeological Survey, The University of Texas. Austin.

Warren, J.E.

1987 A Comprehensive Plan for Investigation and Preservation at Field Fort McIntosh in Laredo, Webb County, Texas. Webb County Historical Commission.

1988 Historical Archaeology at Fort McIntosh in Laredo, Webb County, Texas. Report \#175. The Golf Driving Range Project, Texas Antiquities Committee, Austin.

1989a Historical Archaeology at Fort McIntosh in Laredo, Webb County, Texas. Report \#180. The Texas-Israel Exchange Project, Greenhouse Location. Texas Antiquities Committee, Austin.

1989b A Cultural Resource Survey of the City of San Ygnacio Wastewater Improvement Project, Zapata County Texas. Report \#188, Texas Antiquities Committee, Austin.

1991 Historical Archaeology at Fort McIntosh in Laredo, Webb County, Texas. Report \#240, Texas Antiquities Committee, Austin. 